\title{
Long-run drivers and short-term dynamics of Swedish real house prices
}

\author{
Maher Asal \\ Department of Business, Economics and IT, Hogskolan Vast, Trollhattan, Sweden
}

\begin{abstract}
Purpose - This paper aims to assess the long-run drivers and short-term dynamics of real house prices in Sweden for 1986Q1 to 2016Q4. More specifically, the author examines the extent to which real house prices are determined by affordability, demographics and asset price factors.

Design/methodology/approach - The author conducts a cointegration analysis and applies a vector autoregression model to examine the long- and short-run responsiveness of Swedish real house prices to a number of key categories of fundamental variables.

Findings - The empirical results indicate that house prices will increase in the long run by 1.04 per cent in response to a 1 per cent increase in household real disposable income, whereas real after-tax mortgage interest and real effective exchange rates show average long-term effects of approximately -8 and -0.7 per cent, respectively. In addition, the results show that the growth of real house prices is affected by growth in mortgage credit, real after-tax mortgage interest rates and disposable incomes in the short run, whereas the real effective exchange rate is the most significant determinant of Swedish real house appreciation.

Originality/value - The impact of the two lending restrictions been implemented after the financial crisis the mortgage cap in October 2010 and the amortization requirement in June 2016 - are ineffective to stabilize the housing market. This suggests that macroprudential measures designed to ease pressure on housing prices and reduce risks to financial stability need to focus on these fundamentals and address the issues of tax deductibility on mortgage rates and the gradual implementation of debt-to-income limits to contain mortgage demand and improve households' resilience to shocks.
\end{abstract}

Keywords Cointegration, Macroprudential, Mortgage, Affordability, Autoregression, Amortization

Paper type Research paper

\section{Introduction}

Swedish real house prices (RHPs) have tripled since the mid-1980s, and despite dips occurring in the early 1990s and during the global financial crisis, they are expected to surge to unprecedented new levels. A number of features make the recent real housing cycle, which started in 1996, unprecedented:

- the size and duration of current RHP increases;

- the degree to which these increases are disconnected from the business cycle;

- the degree to which they are predictable in the short- and mid-term; and

(C) Maher Asal. Published by Emerald Publishing Limited. This article is published under the Creative Commons Attribution (CC BY 4.0) licence. Anyone may reproduce, distribute, translate and create derivative works of this article (for both commercial \& non-commercial purposes), subject to full attribution to the original publication and authors. The full terms of this licence may be seen at http://creativecommons.org/licences/by/4.0/legalcode 
IJHMA 11,1

All these features suggest the importance of conducting an analysis to reveal the main drivers behind housing prices. In addition, understanding the causes of house price developments is critical when assessing macroeconomic policies and issues of financial stability.

This paper assesses factors determining Swedish RHPs in the long and short run. Can prices be explained by fundamental factors of demand and supply? If so, which fundamentals play the greatest role? I conduct a cointegration analysis and apply a vector autoregression (VAR) model to examine the long- and short-run responsiveness of Swedish RHPs to a number of key categories of fundamental variables. Using VAR techniques allows the relaxation of assumptions regarding the exogeneity or endogeneity of the explanatory variables.

My study extends the previous literature in two important ways. First, in contrast to previous empirical studies on Swedish housing prices (Hort, 1998; Barot, 2001; Barot and Yang, 2002; Adams and Füss, 2010; Claussen, 2013), which largely use the error correction model (ECM), I use the VAR model, which allows for interaction effects between real housing prices and the related fundamentals. Within the context of the VAR model, I assess typical house price responses to unforeseeable changes over time, i.e. "shocks", in terms of their key determinants. In addition, I use the Granger causality test, variance decomposition and impulse responses to determine the relative importance of each predictor in both the short- and long-run relationships of housing prices without imposing any prior assumptions on such relationships. Second, I consider the impact of Swedish competitiveness as a main driver of Swedish house price appreciation. To my knowledge, no other study has considered this factor for Sweden. I postulate that an improvement in a country's competitiveness due to a weak nominal exchange rate or a lower inflation rate relative to foreign countries has a positive influence on property market prices, particularly for markets where there is substantial demand from non-residents, as is the case for Sweden.

The remainder of this paper is organized as follows. Section 2 describes the evolution of Swedish RHPs. Section 3 offers a review of earlier studies. Section 4 presents an overview of the drivers that presumably affect Swedish RHPs. Section 5 describes the model used in the study. Section 6 describes the data and presents the findings of this study. Section 7 concludes the paper.

\section{The evolution of house prices in Sweden}

Swedish RHPs have tripled since the mid-1980s, and despite dips occurring in the early 1990s and during the global financial crisis, they are expected to increase to unprecedented new levels (Figure 1). Sweden's current house price boom actually began in the mid-1980s. After five years of decline from 1981 to 1985 (37.5 or 7.5 per cent per annum), real prices for owner-occupied houses increased by 34.5 per cent (7 per cent per annum) from 1986 to 1990 in the wake of financial liberalization. This surge was momentarily interrupted in the aftermath of the bank and property crisis of the early 1990s, with RHPs falling 11.2 per cent in 1991 followed by another decline of 15.5 per cent in 1992. By 1995, the real housing price index had dropped to 72 from its peak of 97.7 in 1990. The next boom started in 1996 and was set off by low interest rates and rapid economic growth. With inflation stabilizing after 1996, real after-tax mortgage rates (ATMRs) dropped from a peak of 2 per cent in 1986 to -1 


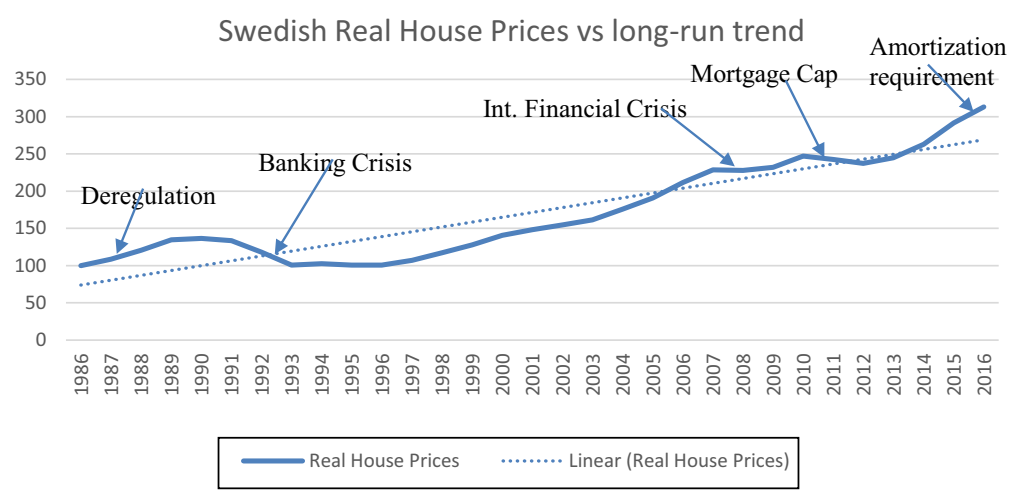

Note: The figure shows the index levels of the RHPs of one- or two-dwelling buildings, i.e. the nominal house prices $(1986=100)$ deflated consumer price indices
Swedish real house prices

Figure 1. Swedish RHPs vs their long-run trend from 1986Q1-2016Q4

$(1986=100)$

per cent in 1994. Since then, with the exception of a few isolated drops, house prices have risen continuously as a result of tax reforms that have strongly encouraged homeownership.

In contrast to many countries, Sweden experienced a relatively mild and short-lived period of house price decline during the global financial crisis of 2008, wherein the average price of houses (one- and two-dwelling buildings) increased by 3 per cent ( -0.3 per cent in real terms) in 2008 (down from 10 per cent (8 per cent in real terms) in 2007, after which dwelling price increases started accelerating, surging to 7.8 per cent $\mathrm{y}-\mathrm{o}-\mathrm{y}$ ( 6.4 per cent in real terms) in 2010. In an attempt to curb this surge in house prices, the Swedish Financial Supervisory Authority introduced a mortgage cap in October 2010 requiring an 85 per cent maximum loan-to-value (LTV) ratio, i.e. the portion of the house purchase price that can be financed with loans. Riksbank, the Swedish central bank, took precautionary action during the second half of 2010, hiking key rates as RHPs fell by 1.8 per cent in 2011. Prices regained momentum in Q4 2012 and have increased continuously ever since. In the third quarter of 2015 , the RHP index stood at 305.13, compared with a value of 277.37 in the fourth quarter of 2014, indicating an astonishing annual growth rate of more than 11 per cent without any sign of reversal. The index has continued to surge, growing 4 per cent through the fourth quarter of 2016 relative to the third quarter, again without any signs of reversal.

A closer examination of Figure 1 reveals strong autocorrelation in the rate of house price changes, indicating that house prices are predictable in the short and medium term. The estimated first-order autoregressive coefficient of changes in RHPs is on the order of 0.51, which is extraordinarily high relative to typical financial assets. It is thus convenient to infer that recent price changes will continue into the near future. However, it is also clear from Figure 1 that there is a tendency for house prices to revert toward their trends in the longer run. Hence, while increasing house prices can be expected to continue for some time, house prices may eventually tend to revert toward the trend. The strong predictability of house price changes in the short and medium run may suggest that the housing market is not informationally efficient. It appears that one could make a fortune by buying when prices are low relative to the long-run trend and by selling when they are high relative to the trend.

The Swedish RHP series is also disconnected from the business cycle. Figure 2 depicts the RHP vs the output gap, measured as the percentage gap between real gross domestic 
IJHMA 11,1

48

Figure 2.

Percentage changes in RHPs and output gap in Sweden (19862016)

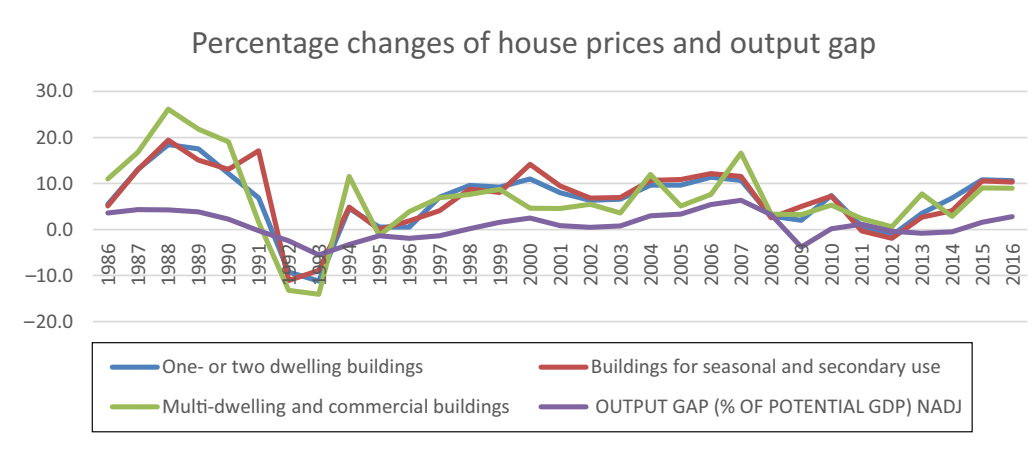

Notes: The figure shows the RHP vs the output gap, measured as the percentage gap between real GDP and the trend or potential real GDP for 1986 to 2016. The figure shows that the Swedish RHP series is disconnected from the business cycle

product (GDP) and the trend or the potential real GDP for 1986Q1 to 2016Q4. The figure shows that house price and business cycle turning points approximately coincide, although prices appear to originate from business cycles during most of the upturns. Over the past two decades, the positive correlation between house prices and the output gap appears to have weakened, as house prices have continued growing despite a slowdown in economic activity. Furthermore, the recent house price boom beginning in 2011 is strikingly out of step with the business cycle.

\section{Literature review}

Several studies have examined the relationship between house prices and supply and demand fundamentals. Ambrose et al. (2013) examined the long-run relation between prices and rents for houses in Amsterdam from 1650 to 2005. They found that house prices and rents are cointegrated, suggesting that they are likely to be determined by the same underlying fundamentals. They also found that the rent-price ratio reveals sustained "bubble" episodes and that changes in house prices and rents are both instruments for correcting disparities between prices and fundamentals. Gallin (2006) examined the long-run equilibrium relationship between house prices and fundamentals such as income, population and user costs using a panel of 95 US metropolitan areas from 1975:Q1 to 2002: Q1. He found no evidence for cointegration and concluded that house prices do not appear to be tied to fundamental values. Xu and Tang (2014) examined determinants of UK house prices using a cointegration and ECM for 1971Q1 to 2012Q4. They found that in the long run, bank credit, construction costs, unemployment rates, interest rates and GDP have a positive impact on house prices, whereas disposable income and money supply have a negative impact.

Gattini and Hiebert (2010) analyzed euro area house prices and their links to fundamentals such as housing investment, real disposable income per capita and a mixed maturity measure of the real interest rate. They found that housing demand and financing cost shocks appear to have contributed considerably to euro area house price dynamics. Adams and Füss (2010) used ECM and data for 15 OECD countries for 1975-2007 to examine the long-term effects and short-term dynamics of macroeconomic variables on housing prices. They found that house prices increase in the long run by 0.6 per cent in response to a 
1 per cent increase in economic activity, whereas construction costs and long-term interest rates show average long-term effects of approximately 0.6 and -0.3 per cent, respectively. They also found that macroeconomic variables significantly affect house prices and that the speed of adjustment is slow (up to 14 years) in the presence of stickiness in residential house prices.

Several Swedish studies have considered the determinants of house prices. Barot (2001) used the ECM for 1970-1997 and found that short-run house prices adjust to changes in the real after-tax long-term interest rate, financial wealth, the employment rate, rents and the population. He also found underlying long-run relationships between RHPs and the following: debt relative to income, debt relative to financial wealth, private housing stock relative to income, rental housing stock relative to private housing stock and real after-tax long-term interest rates. Barot and Yang (2002) used the ECM to examine determinants of house prices and housing investment in Sweden and the UK for 1970-1998. They found that a change in debt has stronger effects for the UK than for Sweden. Although nominal and real interest rates have significant effects on housing prices in both countries, Sweden presents stronger interest rate effects for both the short and long run. In terms of long-run wealth, debt and interest rate effects are more pronounced for Sweden than for the UK.

Frisell and Yazdi (2010) analyzed Swedish house price development trends from the late 1990s. They found that factors such as higher disposable income levels and lower real interest rates can explain almost 90 per cent of all price changes and that it is unlikely that Swedish housing is generally overvalued. Claussen et al. (2011) analyzed the impact of monetary policies on housing prices in Sweden from 1986-2010. Their results suggest that higher incomes, lower real interest rates and a higher preference for housing consumption are important factors spurring the rise in house prices since the mid-1990s. Using the ECM, Claussen (2013) found that rising household income and falling mortgage rates are accountable for the increase in house prices, with no evidence of overpricing from 1986Q12011Q2. Finally, Bergman et al. (2015) studied house price trends in Denmark and Sweden using a bootstrap VAR to estimate the fundamental house price, which is shaped by changes in several macroeconomic variables such as interest rates, disposable income, housing supply and property taxes. They also attempted to evaluate whether house prices are over- or undervalued. They found that short-term interest rates, unemployment, credit growth and consumer confidence have significant effects on the gap between actual and fundamental house prices.

\section{House prices and their underlying determinants}

A continued surge in RHPs could be the result of changes in the factors determining housing demand and supply (i.e. fundamentals) rather than being evidence of an overvaluation or bubble. Based on the literature reviewed above, and for the purposes of this study, I use three categories of explanatory fundamentals that presumably explain Swedish RHPs. The first category consists of affordability measures causing a demand shift for housing and includes real disposable income, real ATMRs, mortgage credit levels, equity prices and demographic factors such as population and employment. I argue that an additional asset pricing variable such as the real effective exchange rate (REER) is an important determinant for countries where foreign investment plays an important role in the economy, as is the case in Sweden. The second category includes supply-side factors such as real private residential investments, real construction costs or the number of completed dwellings. The third category of explanatory variables includes regulatory factors. Changes in building regulations and modifications to zoning laws can cause changes in the housing supply. Potential links between these variables and Swedish housing prices are discussed below. 
IJHMA

11,1

50

\subsection{Affordability measures}

4.1.1 Household income. Most of the research on housing prices reviewed above uses real disposable income as the main determinant of housing prices. An increase in households' real disposable income fuels demand for housing and spurs an increase in housing price appreciation, as the supply of housing is fixed in the short run and restricted by the scarcity of land (Hort, 1998; Barot and Yang, 2002; Meen, 2002; Annett, 2005; Claussen, 2013). By contrast, Schnure (2005) and Case et al. (2013) found a negative elasticity of house prices with respect to income. The argument for this relationship is that households increase their spending as house prices rise, but they do not decrease it when house prices fall. Figure 3 shows the development of real disposable income vs RHPs in Sweden since 1986. After an extended period of negative or stagnant development between 1994 and 1998, real household disposable income (RDISP) continued to grow, due in part to a falling inflation rate. Between 1999 and 2016, real disposable income increased by 71.5 per cent (3.9 per cent per annum). The figure shows that income did not keep pace with the increase in house prices during this period and that RHPs have increased considerably more than incomes since 1998. This implies that an increase in RHPs is not fully captured by real disposable income and that other factors may contribute to the widening gap between RHPs and real disposable income in recent years.

4.1.2 After-tax mortgage rate. The economic literature (Girouard et al., 2006; Adams and Füss, 2010) suggests that an increase in the real interest rate increases the yield of other fixed-income assets, such as bonds, relative to that of real estate, thus shifting demand from real estate to other assets. In addition to depressing the housing supply, a higher real interest rate is also reflected in higher mortgage rates, which reduce demand and further reduce house prices, making renting more attractive than buying. Figure 4 shows nominal and real ATMRs vs percentage changes in real GDP for Sweden. The figure shows that the real ATMR has reached and remained at a historically low level, particularly since the financial crisis of 2008-2009. The repo rate in the second half of 2009 and the first half of 2010 fell to 0.25 per cent, and the variable mortgage rate decreased as well, reaching a lowest

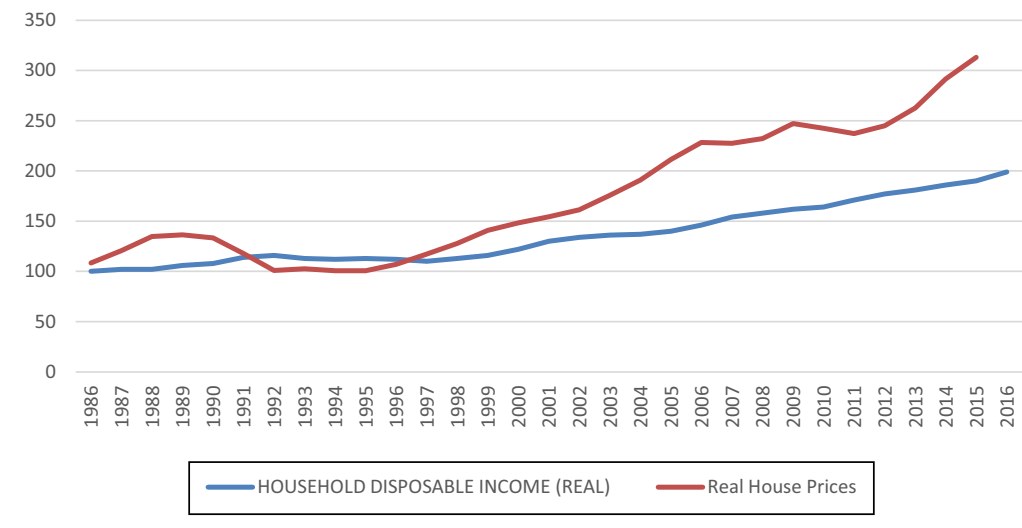

Figure 3. RHPs vs Real disposable income in Sweden $(1986=100)$
Notes: The figure shows the development of real disposable income vs RHPs in Sweden since 1986. The figure shows that income did not keep pace with the increase in house prices during this period and that RHPs have increased considerably more than incomes since 1998 


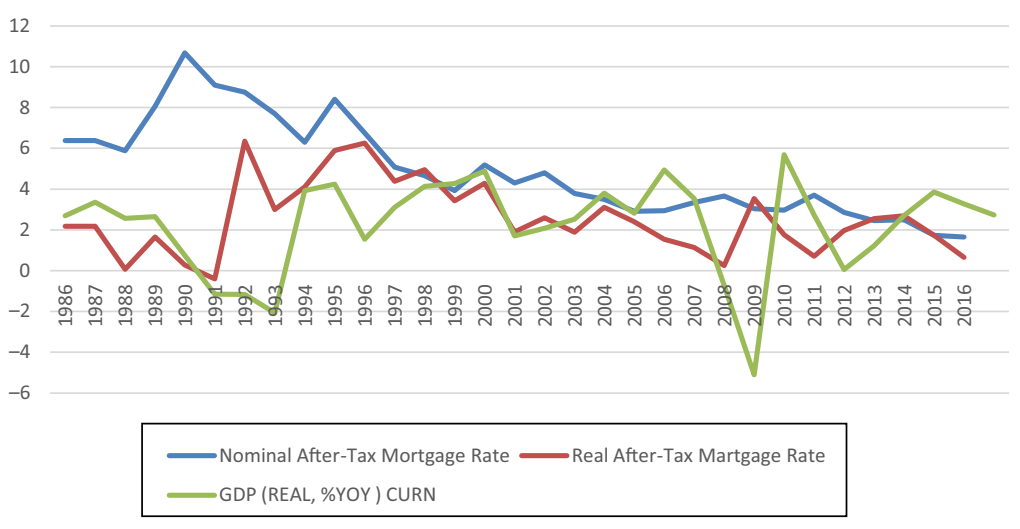

Notes: The figure shows that the after-tax real mortgage rate is calculated as $r_{t}$ $\left.\left(1-\tau_{t}\right)-\pi_{t}\right)$, where $r_{t}$ is the five-year fixed mortgage rate, $\tau_{t}$ is the tax deductibility, which is 0.5 until 1990 and 0.3 thereafter, and $\pi_{t}$ is the inflation rate
Swedish real house prices

Figure 4. Percentage changes in Swedish real GDP vs Ex-post nominal and real ATMR

point of approximately 1.40 per cent. Sweden's benchmark interest rate reached 0 per cent in October 2014 following seven rate cuts starting in December 2011. The central bank rate imposed a negative repo rate of -0.1 per cent in February 2015, which was extended in March to -0.25 per cent as the central bank continued to support the rise in inflation and to ensure that long-term inflation expectations were in line with the inflation target. The interest rates offered by home credit institutions followed the declining central bank rates, reaching 1.82 per cent in 2016. High RHPs are also associated with a tax system that has fully deductible interest payments, which can make real after-tax interest rates low or even negative; Sweden's marginal tax rate was set at 50 per cent until 1991, when it was dropped by a tax reform to 30 per cent.

4.1.3 International competitiveness. An improvement in a country's competitiveness due to a weak nominal exchange rate or a lower inflation rate relative to those of foreign countries can drive up housing prices. In addition to attracting foreign tourists, an improvement in competitiveness triggers the sale of houses and other assets in a country, and only buyers who can pay in the stronger foreign currency can pay the selling price. In countries where foreign investment plays an important role in the economy, such as Sweden, improvements in competitiveness are typically related to housing booms. This occurs in combination with a low housing supply, which increases housing prices. Evidence that foreign buyers push up housing prices can be found the literature. Examples of such studies include Sá et al. (2014) and Fratzscher et al. (2007) for the OECD; Mendicino and Punzi (2014) and Justiniano et al. (2014) for the USA; Akbari and Aydede (2012) and Gyimah et al. (2005) for Canada; and Gonzalez and Ortega (2013) for Spain.

Figure 5 shows the Swedish REER against its largest trade partner's vs RHPs for 19862016. The figure shows that the REER has been declining over time, indicating an increase in trade competitiveness and implying that exports become cheaper as imports become more expensive, which explains Sweden's high and persistent current account surplus[1]. Indeed, improvements in Swedish trade competitiveness together with several favorable tax reforms have encouraged foreign buyers, mostly from neighboring Scandinavian countries and Germany. According to Statistics Sweden, 37,438 vacation homes in Sweden are owned by foreigners, 


\section{IJHMA 11,1}

\section{2}

Figure 5. RHPs and REER from 1986-2016

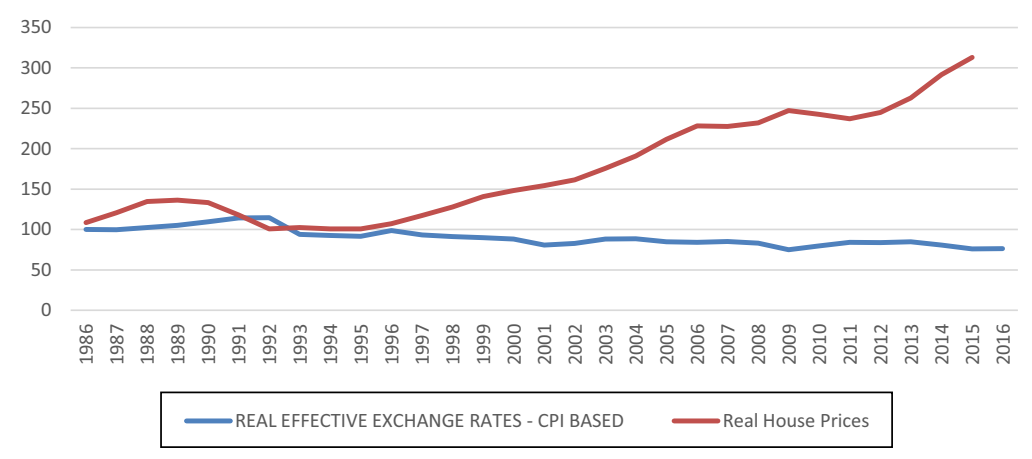

Notes: The figure shows the Swedish REER against its largest trade partner's vs the RHPs for 1986-2016. An increase in REER implies that exports become more expensive and imports become cheaper; therefore, an increase indicates a loss in trade competitiveness

representing an increase of 107 per cent from 2000 levels. In 2016, foreign ownership of vacation homes in Sweden reached 6.5 per cent, whereas expatriate Swedes owned 2.3 per cent.

4.1.4 Demographics. Demographic factors, which describe the composition of a population (e.g. population growth, age and migration patterns), affect not only overall housing prices but also what types of properties are in demand. The Swedish population has been increasing rapidly since 2000 and started to accelerate in 2006 due to increased net migration. A record high immigration rate of 160,000 in 2015 alone increased demand for housing, particularly in the country's three largest cities: Stockholm, Gothenburg and Malmo. Furthermore, immigration is most common among persons aged 20-35, and this demographic group is especially accountable for the increasing demand for housing. Regarding household types, the most common household type in Sweden in 2015 was a single person living alone, accounting for 47.9 per cent of households, compared with 32.7 per cent for the EU-28. Thus, immigration has spurred not only population growth but also demographic changes, e.g. a higher proportion of single people living alone presumably led to increased demand for houses and therefore increased housing prices.

Another key factor that affects housing demand and prices is the overall health of the economy. Rising unemployment reduces demand for housing and makes house purchases less affordable. The rate of unemployment dropped from a peak of 10.5 per cent in 1997 to 5.83 per cent in 2001. Since then, with the exception of a few isolated increases occurring in 2010 and 2013, unemployment rates have declined continuously. Meanwhile, the employment rate has continued to surge in recent years, rising from 57.83 per cent in 2010 to over 60 per cent in 2016.

4.1.5 Mortgage credit to households. A growth in mortgage credit increases households' financing ability and stimulates demand for housing. Figure 6 shows the volume of lending to households by monetary and financial institutions for housing purchases against long-run trends for 1986 to 2016. The deregulation of the Swedish capital market in the second half of the 1980s resulted in lending expansion from financial institutions to the private non-financial sector from 12 per cent (4.6 per cent in real terms) in 1985 to 25 per cent (20.9 per cent in real terms) in 1986. In addition, several innovations in the mortgage market have expanded the borrowing opportunities available to Swedish households. These developments, coupled with record low borrowing costs, resulted in higher levels of lending growth in the beginning of the 


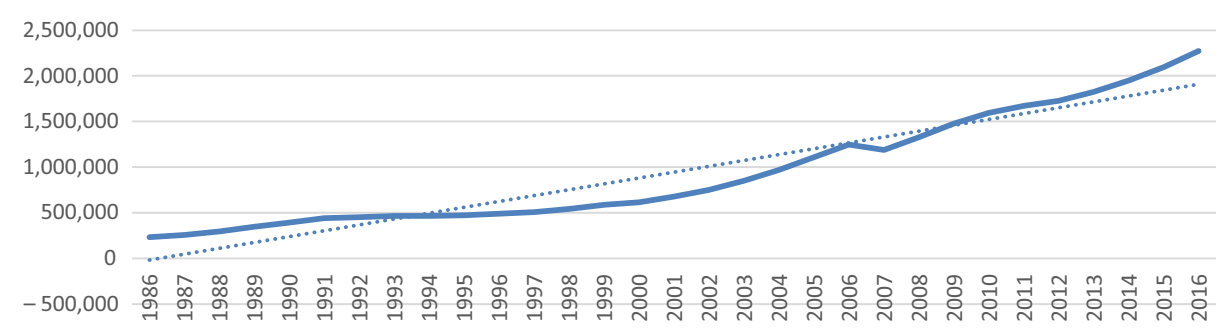

MFI'S LENDING TO HOUSEHOLDS INCL NPISH-HOUSING CREDIT INST.

......... Linear ( MFI'S LENDING TO HOUSEHOLDS INCL NPISH-HOUSING CREDIT INST.)

Note: The figure shows the volume of lending to households by monetary and financial institutions for housing purchases against long-run trends for 1986 to 2016
Swedish real house prices

53

Figure 6.

Swedish lending to households including NPISH-MFI, housing credit inst., 1986-2016

2000s, as many banks were keen to provide mortgages. From 2000 to 2015, housing lending to households soared 137 per cent, with an average of 8.5 per cent per year. Since 2009, the debt level has been increasing above its long-run trend line without any indication of reversion. In 2011, however, mortgage credit growth slowed as banks applied stricter requirements on their customers, and in October 2010, the Financial Supervisory Authority introduced a mortgage cap of 85 per cent LTV, which also temporarily dampened lending growth. Even lower borrowing costs in recent years have caused an astonishing surge in housing loans to households, which rose 8.4 per cent in 2016 to SEK 2.27tn, up from SEK 2.09tn in 2015. As high volumes of real estate credit and strong price growth are signs of banking crises, a loan amortization requirement was applied in 2016[2]. Sweden has seen household indebtedness rise from 90 per cent of disposable income in 1995 to a historical high of 190 per cent in 2016. Mortgage lending as measured by the percentage of GDP has also been accelerating over the past 10 years, increasing from 20-30 per cent of GDP to approximately 60 per cent (Swedish National Board of Housing, Building and Planning, 2012).

4.1.6 Legislation. Legislation is another factor that can have a substantial impact on housing demand and prices. Sweden has undertaken several measures designed to encourage homeownership. In 2005, the country abolished the inheritance tax. In 2007, the tax on imputed housing rent was abolished, making ownership preferable to renting. The Swedish property tax was nearly eliminated in 2008 , and 30 per cent of mortgage interest payments became tax deductible, which encouraged home buying and reduced the incentive to amortize principal. According to the index for tax incentives for home ownership, fiscal conditions support homeownership in Sweden more than in other European countries (European Commission, 2014). As a result, owner-occupancy rates in Sweden increased from 68 per cent in 2007 to approximately 71 per cent in 2015, compared with 53 per cent in Germany and 63 per cent in Denmark.

\subsection{Supply of housing and production costs}

One can study how well housing construction has developed in relation to the significant increase in demand factors over the past 30 years by determining the number of completed homes. Figure 7 lists completed dwellings classified by building type between 1986 and 2016. As the figure shows, housing construction has been very limited from a historical perspective and in light of the substantial increase in urbanization and household demand 
IJHMA 11,1

\section{Figure 7.}

Number of completed dwellings in Sweden, 1986-2016 for housing, as noted above. One of the most significant declines in housing construction occurred in the mid-1990s in the wake of the banking crisis, the subsequent economic downturn and a decline in interest subsidies for construction plans. This, in conjunction with tax reforms instituted in 1993 that provided funding conditions for public housing companies similar to those for private participants in the market, resulted in a substantial decline in housing construction[3]. Decades of low construction levels combined with rapidly growing demand have rendered new homes scarce.

One could argue that higher construction costs are to blame for the very low construction rates in Sweden. The effects of construction costs on new housing construction can be determined from the ratio of housing prices to construction costs (i.e. Tobin's $\mathrm{Q}$ for residential investment or the profitability measure). Figure 8 depicts the number of completed dwellings and construction profitability, as measured by Tobin's Q. An increase in house prices raises housing values relative to construction costs, which results in higher Tobin's Q values and makes housing construction more profitable. The figure shows that Swedish housing supplies seem to be unresponsive to the recent increase in Tobin's Q. Indeed, the contemporaneous cross-correlation coefficient between Tobin's Q and the number of completed homes was found to be zero. The first significant correlation coefficients are found at a lag and lead of 7 (almost two years), with values of -0.4 and 0.2 , respectively. Overall, the results indicate that the rate of housing construction in Sweden over the past 30 years has not kept pace with the increase in housing demand, as reflected in higher housing prices and housing shortages in many parts of the country. As house prices have been increasing much faster than production costs over this period, neither construction costs nor housing investment profitability explain why more housing has not been built in Sweden.

\section{The model}

In this paper, a stock-flow model of housing supply and demand is utilized to characterize the relationship between house prices and fundamentals. I follow the literature (DiPasquale and Wheaton, 1996; Adams and Füss, 2010) and use the following long-run model of supply and demand, where the long-run demand for the stock of housing services, $D_{t}$, is:

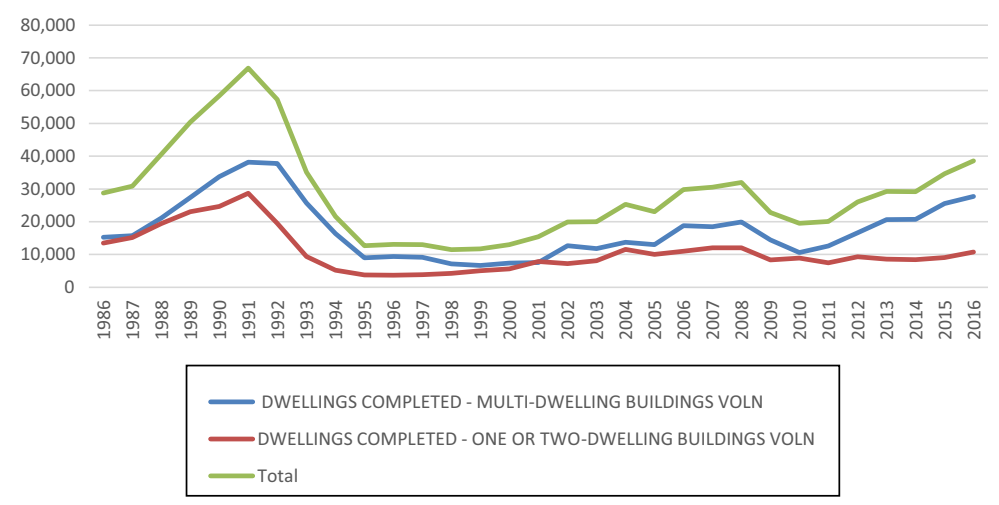

Notes: The figure shows the number of completed dwellings classified by building type between 1986 and 2016. As the figure shows, housing construction has been very limited from a historical perspective 


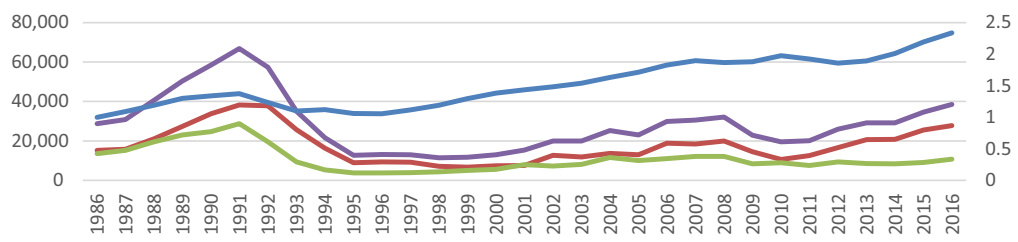

Swedish real house prices

$$
\begin{aligned}
& \text { DWELLINGS COMPLETED - MULTI-DWELLING BUILDINGS VOLN } \\
& \text { DWELLINGS COMPLETED - ONE OR TWO-DWELLING BUILDINGS VOLN } \\
& \text { Total } \\
& \text { Tobin's Q }
\end{aligned}
$$

Notes: The figure shows the number of completed dwellings (left axis) and construction profitability, as measured by Tobin's Q (right axis). The figure shows that Swedish housing supplies seem to be unresponsive to the recent increase in Tobin's Q

$$
D_{t}=\alpha-\beta_{1} p_{t}+\beta_{2} A F_{t}-\beta_{3} r_{t}+\varepsilon_{t}
$$

Equation (1) states that higher house prices $p_{t}$ decrease demand for home ownership; higher affordability measures, $A F_{t}$, as described in Section 4, have a positive effect on demand; and higher mortgage rates, $r_{t}$, reduce demand. $\varepsilon_{t}$ captures other demand shifters affecting housing demand at the micro level, such as the social environment, tax regulations and mortgage market characteristics. Similarly, the supply of housing, $\mathrm{S}_{\mathrm{t}}$, can be expressed as:

$$
S_{t}=\eta+\gamma_{1} p_{t}-\gamma_{2} R C C_{t}+v_{t}
$$

Equation (2) states that higher house prices create incentives for investors and increase the housing supply, whereas higher real construction costs, RCC, decrease the supply. $\eta$ is a constant term and $v_{\mathrm{t}}$ is a white noise error term. Solving for house prices in equilibrium where supply equals demand yields:

$$
\begin{gathered}
p_{t}=\alpha^{*}+\beta_{2}^{*} A F_{t}+\gamma_{2}^{*} R C C_{t}-\beta_{3}^{*} r_{t}+\varepsilon_{t}^{*} \\
\text { where } \alpha^{*}=\frac{\alpha-\eta}{\gamma_{1}+\beta_{1}}, \gamma_{2}^{*}=\frac{\gamma_{2}}{\gamma_{1}+\beta_{1}}=\frac{\partial p}{\partial R C C}, \beta_{2}^{*}=\frac{\beta_{2}}{\gamma_{1}+\beta_{1}}=\frac{\partial p}{\partial A F}, \\
\beta_{3}^{*}=\frac{\beta_{3}}{\gamma_{1}+\beta_{1}}=\frac{\partial p}{\partial r}, \text { and } \varepsilon_{t}^{*}=\varepsilon_{t}-v_{t}
\end{gathered}
$$

I expect to find a positive sign for $\beta_{2}^{*}$ and $\gamma_{2}^{*}$ and a negative sign for $\beta_{3}^{*}$. Incorporating the affordability measures and construction costs into equation (3) generates the following testable long-run model for Sweden, which I apply in the empirical part of this study:

$$
\begin{aligned}
p_{t}= & \alpha+D_{I S P_{t}-A T M R_{t}}+\text { RMCH }_{t}-\text { REER }_{t}+S T O C K_{t}+P O P_{t}+- \text { UNEMP }_{t} \\
& +R C C_{t}+\varepsilon_{t}
\end{aligned}
$$

Figure 8.

Tobin's Q and number of completed dwellings $(1986=$ 
IJHMA 11,1

where $p_{t}$ is the RHP for one- and two-family dwellings, $D I S P_{t}$ is the RDISP, $A T M R_{t}$ is the after-tax real mortgage interest rate, $R E E R_{t}$ is the REER, $P O P_{t}$ is the population, $R M C H_{t}$ is the real mortgage credit to households, $U N E M P_{t}$ is the unemployment rate, $S T O C K_{t}$ is the stock market index and is used as a proxy of financial wealth of households, $R C C_{t}$ is the real construction cost and $\varepsilon_{t}$ is a white noise error term. Assuming that unobserved components of the model are stationary and that the coefficients of explanatory variables do not change, house prices will be cointegrated with those fundamentals that also have a unit root. Finally, the housing stock, $\mathrm{S}_{\mathrm{t}}$, evolves over time with housing investment, $H I N V_{t}$, through the following relation:

$$
S_{t}=H I N V_{t}+(1-\delta) \times S_{t-1}
$$

where $\delta$ is the rate of depreciation of the housing stock. Housing investment is in turn determined by the profit incentive, as represented by the ratio of housing prices to the cost of new construction (e.g. Tobin's Q) and to the interest rate, reflecting the cost of financing investments, $r_{t}$, so that:

$$
H I N V=h\left(q_{t}, r_{t}\right) \quad \text { where } \mathrm{q}=\mathrm{P} / \mathrm{CC}
$$

While a higher q increases housing investment, a higher $r_{t}$ depresses housing investment. A higher interest rate depresses both supply and demand. The average q is, in turn, defined here as an index of the market price (P) to the construction price (CC). In the long-run equilibrium, the value of Tobin's $\mathrm{Q}$ converges to 1 , implying that asset prices converge toward construction costs, but in the short run, Q can diverge from 1 .

\section{Empirical results}

6.1 Empirical methodology

I use the unrestricted VAR model, which is considered one of the most successful and flexible models for capturing the interaction between real housing prices and their determinants. Furthermore, the VAR model can often provide forecasts superior to those of univariate time series models (Brooks, 2014), and it summarizes structural analyses including Granger causality tests, the computation of impulse response functions and forecast error variance decompositions. Statistical tests are applied to determine the appropriate lag length $\mathrm{p}$, and the long-run relation between real housing prices and their determinants is also dictated on the basis of the estimated cointegration vector.

\subsection{Data and variable descriptions}

In this section, I briefly describe the data measurements and transformations used in this study. Quarterly data for 1986Q1 to 2016Q4 are used in this study. The following variables are considered: the RHP, which is defined as the nominal price of single-family houses (småhus) deflated by the consumer price index; RDISP, which is defined as the nominal household disposable income deflated by the consumer price index; the real ATMR, which is defined as the mortgage rate for five years adjusted for inflation and tax deductibility; real mortgage credit to households (RMCH) for house purchases, which is defined as loans from the Monetary Financial Institution for housing purchases deflated by the consumer price index; the stock price index (STOCK), which is defined as the OMXS30 index; the REER, which is defined as the weighted average of Sweden's currency relative to a basket of the strongest trade currencies, adjusted for the effects of inflation; the real construction cost (RCC), which is defined as the construction cost for one- or two-dwelling buildings 
(faktoprisindex) deflated by the consumer price index; the population (POP); and the unemployment rate (UNEMP). All data are transformed to their natural logarithms with the exception of ATMR. In this study, the proposition of McCue and Kling (1994) and Brooks and Tsolacos (1999) that house prices are affected by the overall stock market is taken into account. Following the procedure proposed by these authors, I regress house prices on the OMXS30 index, saving the residuals. These residuals, denoted by RESOMX, are linearly independent of stock market effects (as they are now void of contemporaneous general stock market effects). This procedure, known as orthogonalization, separates out components of RHPs that are linearly and contemporaneously related to movements in the general stock market (for a description of the variables and data sources, see Table A1 in the Appendix 1).

Constructing the VAR model first involved addressing issues of multicollinearity arising among the variables in equation (4). For this reason, I estimated the contemporaneous (zero lag) and lag 12 correlation coefficients for the variables in the system. The results (not shown here) reveal a strong correlation between the real construction costs (RCC) on the one hand and real disposable income (RDISP) and the RMCH on the other, generating coefficient values of 0.98 and 0.97 , respectively. I thus replaced the real construction cost with real housing investment (RHINV), which was measured by real gross fixed capital formation for housing deflated by CPI, in long-run estimates to avoid a near perfect multicollinearity problem. Strong correlations were also found between RDISP and the RMCH, generating a coefficient value of 0.94. I therefore use RDISP and RMCH interchangeably[4]. Finally, the population variable was found to be highly correlated with several other variables, and I thus excluded this variable from the long-run equation. However, the percentage changes of the excluded variables were incorporated in the short-run dynamic estimate.

Table I shows simple correlations between the following seven fundamental variables used in the long-run equation: RHP, real disposable income (RDISP), after-tax mortgage real interest rate (ATMR), the REER, RHINV, the proxy for the stock market (RESOMX) and unemployment (UNEMP). A few features of the relationship between real housing prices and their determinants are worth noting. First, there are strong negative correlations between the real mortgage interest rate and real housing prices. Second, there are strong positive correlations between real housing prices and real disposable income, generating a correlation coefficient of 0.91 . Third, there is a strong negative correlation between the REER and real housing prices, generating a correlation coefficient of -0.72 . Fourth, these

\begin{tabular}{lrrrrrrr}
\hline Variable & RHP & RDISP & ATMR & REER & RHINV & UNEMP & RESOMX \\
\hline RHP & 1.00 & & & & & & \\
RDISP & 0.91 & 1.00 & & & & & \\
ATMR & -0.08 & 0.08 & 1.00 & & & & \\
REER & -0.72 & -0.77 & -0.30 & 1.00 & & & \\
RHINV & 0.32 & 0.08 & -0.47 & 0.24 & 1.00 & & \\
UNEMP & 0.21 & 0.44 & 0.46 & -0.53 & -0.60 & 1.00 & \\
RESOMX & 0.32 & 0.46 & 0.38 & -0.66 & -0.69 & 0.68 & 1.00
\end{tabular}

Notes: The table reports the contemporaneous cross-correlations for the variables. RHP refers to the real house price index; RDISP refers to real household disposable income; ATMR refers to the real after-tax mortgage rate; REER refers to real effective exchange rates; RHINV refers to real housing investment; UNEMP refers to the unemployment rate; and RESOMX refers to the residual of the stock price index. All data are transformed to their natural logarithms, with the exception of ATM, RESOMX and UNEMP. Using RMCH rather than real disposable income provided similar correlation coefficients. Using RMCH rather than real disposable income provided similar results

\section{$-1$}


IJHMA 11,1

58

correlation coefficients suggest an absence of strong multicollinearity among explanatory variables.

6.2.1 Lag length. The second phase of constructing the VAR model involved determining the appropriate lag length. I needed to use the same number of lags for all variables in all equations for the VAR to be unrestricted. Various criteria were applied to determine the appropriate lag length, and the corresponding results are shown in Table II. The Schwarz and Hannan-Quinn information test results shown in Table II indicate that the VAR regression model is optimal for a four-period lag, although the other tests suggest an eightperiod lag. It is also important to note that such a lag length allows the model to include sufficient degrees of freedom. Therefore, four to eight lags were used in estimating the shortrun dynamics of the changes in RHPs.

6.2.2 Granger causality test. As the stock-flow model has a supply and demand side, I decided to test for the direction of causality among the seven variables in the system using the concept of Granger causality. One would expect the RHP determinants to be exogenous and therefore would expect Granger caused house prices. However, feedback may exist. Table III reports the results of the Granger causality test conducted between the levels RHPs and their determinants for up to 12 lags. The estimated F-statistics of the causality test suggest that six determinants Granger cause RHPS: RDISP, real mortgage credit, real after-tax mortgage interest rates, REERs, real housing investment and the proxy of the stock market (RESOMX). Only house prices, real housing investment and REERs have bilateral feedback effects (simultaneous). Thus, the hypothesis that unemployment Granger causes RHPs is rejected.

\subsection{Analysis and long-run relationships}

The long-run analysis was conducted in three phases. First, I tested the variables for stationarity through a unit-root test. I then conducted cointegration tests to determine longterm equilibrium relationships and estimated long-term relationships.

6.3.1 Stationarity testing. When using the VAR model in its long-run setting, it is essential that all VAR components are stationary to carry out joint significance tests on the lags of the variables. All variables were thus subjected to the augmented Dickey-Fuller (ADF) test, which is a precondition to the application of cointegration analysis. Table IV reports the $\mathrm{ADF}$ test statistic results for the presence of unit roots in levels with the inclusion of only constant and constant plus trend. The table includes three sets of variables:

\begin{tabular}{lrrrrrr}
\hline Lag & LogL & LR & FPE & AIC & SC & HQ \\
\hline 0 & -187.80 & NA & 0.00 & 3.36 & 3.52 & 3.43 \\
1 & 866.52 & 1963.21 & 0.00 & -13.97 & -12.65 & -13.43 \\
2 & 977.82 & 193.81 & 0.00 & -15.05 & -12.56 & -14.04 \\
3 & 1058.89 & 131.39 & 0.00 & -15.60 & -11.95 & -14.12 \\
4 & 1241.41 & 273.79 & 0.00 & -17.90 & $-13.08^{*}$ & $-15.94^{*}$ \\
5 & 1284.62 & 59.60 & 0.00 & -17.80 & -11.82 & -15.38 \\
6 & 1326.71 & 52.97 & 0.00 & -17.68 & -10.54 & -14.78 \\
7 & 1373.66 & 53.43 & 0.00 & -17.65 & -9.34 & -14.28 \\
8 & 1441.12 & $68.62^{*}$ & 0.00 & $-17.96^{*}$ & -8.50 & -14.12
\end{tabular}

Table II.

Lag order selected by the criterion in VAR
Notes: Sample period: 1986Q1-2016Q4; The table shows various criteria determining the appropriate lag length; *indicates lag order selected by the criterion at the 5\% level. LR refers to the sequential modified LR test statistic; FPE refers to the final prediction error; AIC refers to the Akaike information criterion; SC refers to the Schwarz information criterion; and HQ refers to the Hannan-Quinn information criterion 


\begin{tabular}{lccc}
\hline Null hypothesis & $F$-statistic & Prob. & $\begin{array}{c}\text { Swedish real } \\
\text { house prices }\end{array}$ \\
\hline RDISP does not Granger cause RHP & 2.82 & $0.00^{*}$ & \\
RHP does not Granger cause RDISP & 1.42 & 0.17 & $0.01^{*}$ \\
RMCH does not Granger cause RHP & 2.36 & 0.86 & $0.02^{* *}$ \\
RHP does not Granger cause RMCH & 0.57 & 0.71 & $0.02^{* *}$ \\
ATMR does not Granger cause RHP & 2.18 & $0.04^{* *}$ & $\mathbf{5 9}$ \\
RHP does not Granger cause ATMR & 0.74 & $0.03^{* *}$ \\
REER does not Granger cause RHP & 2.24 & $0.01^{*}$ \\
RHP does not Granger cause REER & 1.91 & 0.63 \\
RHINV does not Granger cause RHP & 2.08 & $0.00^{*}$ \\
RHP does not Granger cause RHINV & 2.47 & $0.02^{* *}$ \\
UNEMP does not Granger cause RHP & 0.82 & 0.23
\end{tabular}

Notes: Sample period: 1986Q1-2016Q4; The table reports the results of the Granger causality test conducted between the log levels of RHPs and their determinants for up to 12 lags. The estimated F-statistics and probabilities are reported; *indicates statistical significance at the $1 \%$; **5\%; *** $10 \%$ levels. All data are transformed to their natural logarithms, with the exception of ATMR, RESOMX and UNEMP

Table III.

Pairwise granger causality tests

\begin{tabular}{|c|c|c|c|c|c|c|c|c|c|}
\hline \multirow[b]{3}{*}{ Variable } & \multicolumn{4}{|c|}{ Level } & \multicolumn{5}{|c|}{ First difference } \\
\hline & \multicolumn{2}{|c|}{ Const. } & \multicolumn{2}{|c|}{ Const. + Trend } & \multicolumn{2}{|c|}{ Const. } & \multicolumn{3}{|c|}{ Const. + Trend } \\
\hline & $t$-stat. & Prob. ${ }^{a}$ & $t$-stat. & Prob. $^{\mathrm{a}}$ & $t$-stat. & Prob. $^{a}$ & $t$-stat. & Prob. ${ }^{a}$ & Order $5 \%$ \\
\hline RHP & 0.09 & 0.96 & -2.9 & 0.14 & -3.3 & 0.016 & -3.4 & 0.051 & $\mathrm{I}(1)$ \\
\hline RDISP & 1.37 & 0.99 & -1.1 & 0.93 & -15.0 & 0 & -15.4 & 0 & $\mathrm{I}(1)$ \\
\hline ATMR & -0.98 & 0.75 & -3.4 & 0.05 & -9.0 & 0 & -9.02 & 0 & $\mathrm{I}(1)$ \\
\hline REER & -1.52 & 0.51 & -3.2 & 0.09 & -7.9 & 0 & -7.89 & 0 & $\mathrm{I}(1)$ \\
\hline HINV & -1.58 & 0.48 & -1.4 & 0.85 & -5.0 & 0 & -5.22 & 0 & $\mathrm{I}(1)$ \\
\hline RESOMX & -1.91 & 0.32 & -2.0 & 0.57 & -8.5 & 0 & -8.51 & 0 & $\mathrm{I}(1)$ \\
\hline $\mathrm{RMCH}$ & 1.13 & 0.99 & -0.93 & 0.94 & -8.8 & 0 & -8.9 & 0 & $\mathrm{I}(1)$ \\
\hline UNEMP & -2.11 & 0.23 & -1.9 & 0.59 & -4.9 & 0 & -4.99 & 0 & $\mathrm{I}(1)$ \\
\hline \multicolumn{10}{|c|}{ Test critical values } \\
\hline $1 \%$ level & -3.489 & & -4.043 & & -3.489 & & -4.041 & & \\
\hline $5 \%$ level & -2.887 & & -3.451 & & -2.887 & & -3.45 & & \\
\hline $10 \%$ level & -2.58 & & -3.151 & & -2.58 & & -3.15 & & \\
\hline
\end{tabular}

Notes: ${ }^{\text {a }}$ The table reports the ADF test, including constant and constant + trend; the lag length criteria: automatic selection based on the Schwarz information criterion; $t$-statistics; and probability. The results show that all fundamental variables included in the VAR are nonstationary [e.g. I(1)]. For the definition of the variables, see Table I

Table IV.

Results of ADF test statistic for the presence of unit root

fundamental variables, which are assumed to affect RHPs in the long run, transformed variables and other macroeconomic variables assumed to affect RHPs in the short run. The results shown (Columns 2-5) in the upper panel of Table IV do not reject the null hypothesis of the presence of unit roots (i.e. non-stationary) in levels for all fundamental variables at 5 per cent significance level, which is the precondition for the application of cointegration 
IJHMA 11,1

60

analysis (Engle and Granger, 1987). I repeated the test using the first differences of each series (Columns 6-9) and found that I can reject the null hypothesis of non-stationarity. Thus, the assumption that all fundamental variables included in the VAR are I (1) processes appears to be validated by the data.

6.3.2 Cointegration testing. Next, I tested for cointegration. I applied the Johansen test, which is powerful even when the sample size is small, as is the case for this study (sample size $=115$ ). The Johansen procedure involves the use of two test statistics for cointegration: the trace test, which tests the hypothesis stating that there are at most $r$ cointegrating vectors, and the maximum eigenvalue test, which tests the hypothesis stating that there are $r+1$ cointegrating vectors. The corresponding test results are presented in Table V. The null hypothesis of no cointegration is rejected because statistics $>$ critical values. The trace test results reveal four cointegrating equations, and the maximum eigenvalue test results reveal two cointegrating equations at the 0.05 level for the seven variables in the system, showing that house prices are determined by an equilibrium between housing supply and demand in the long run. Given that there are at least two cointegrating relationships between these variables, I proceed to estimate the long-run relationship of RHP determinants[5].

6.3.3 Long-run relationships. Various specifications of the long-run determinants of RHPs were examined using equation (4). I report in Table VI only two specifications of the long-run relation for the baseline model estimated for 1986Q1 to 2016Q4. In Specification II, I replace RDISP with $\mathrm{RMCH}$ because nearly all households must borrow money from financial institutions when buying a house. Despite the fact that the adjusted $R^{2}$ is higher and the sum of squared residuals is lower in Specification II, I found Specification I to be the best model identified, and I refer to this model in the remainder of this paper. Specification I is consistent with a life-cycle model in which debt is not a long-run driver of consumption, including consumption of housing services. In addition, as shown in Table VI (Columns 2-4), the estimated coefficients of the long-run relation are significant, and the corresponding signs are as expected.

More specifically, the results show that the real ATMR is the most important variable in explaining RHP appreciation in the long run: RHPs fall by 8 per cent in the long run in

\begin{tabular}{|c|c|c|c|c|c|c|c|c|c|}
\hline \multirow[b]{2}{*}{ No. of CE(s) } & \multicolumn{3}{|c|}{ Trace test 0.05} & \multirow[b]{2}{*}{ Prob.** } & \multicolumn{5}{|c|}{ Maximum Eigenvalue test 0.05} \\
\hline & $\begin{array}{l}\text { Eigen } \\
\text { value }\end{array}$ & Statistic & $\begin{array}{c}\text { Critical } \\
\text { value }\end{array}$ & & No. of CE(s) & $\begin{array}{l}\text { Eigen } \\
\text { value }\end{array}$ & Statistic & $\begin{array}{c}\text { Critical } \\
\text { value }\end{array}$ & Prob.** \\
\hline None* & 0.55 & 258.7 & 159.53 & 0.000 & None* & 0.55 & 95.01 & 52.36 & 0.00 \\
\hline At most $1^{*}$ & 0.38 & 163.7 & 125.61 & 0.000 & At most $1^{*}$ & 0.38 & 56.79 & 46.23 & 0.003 \\
\hline At most $2 *$ & 0.23 & 106.9 & 95.75 & 0.007 & At most 2 & 0.23 & 30.91 & 40.07 & 0.36 \\
\hline At most $3 *$ & 0.22 & 76.0 & 69.81 & 0.015 & At most 3 & 0.22 & 29.57 & 33.87 & 0.15 \\
\hline At most 4 & 0.16 & 46.4 & 47.85 & 0.068 & At most 4 & 0.16 & 21.81 & 27.58 & 0.23 \\
\hline At most 5 & 0.11 & 24.6 & 29.79 & 0.176 & At most 5 & 0.11 & 13.96 & 21.13 & 0.36 \\
\hline At most 6 & 0.08 & 10.6 & 15.49 & 0.233 & At most 6 & 0.08 & 10.54 & 14.26 & 0.17 \\
\hline At most 7 & 0.001 & 0.1 & 3.84 & 0.738 & At most 7 & 0.001 & 0.11 & 3.84 & 0.73 \\
\hline
\end{tabular}

Table V.

Cointegration test Johansen method: Null H: No cointegration
Notes: The table shows the results of the Johansen test for cointegration using two test statistics: the trace test and the maximum eigenvalue test. While the trace test reveals four cointegrating equations, the maximum eigenvalue test revels two cointegrating equations between RHP RDISP ATMR REER RHINV UNEMP and RESOMX. All data are transformed to their natural logarithms, with the exception of ATM, RESOMX and UNEMP; *denotes rejection of the null hypothesis of no cointegration at the 0.05 level; ***MacKinnon-Haug-Michelis (1999) $p$-values 


\begin{tabular}{|c|c|c|c|c|c|c|c|}
\hline \multirow[b]{2}{*}{ Variable } & \multicolumn{3}{|c|}{ Specification I } & \multicolumn{3}{|c|}{ Specification II } & \multirow{2}{*}{$\begin{array}{l}\text { Swedish real } \\
\text { house prices }\end{array}$} \\
\hline & Coefficient & $t$-statistic & Prob. & Coefficient & $t$-statistic & Prob. & \\
\hline RDISP & 1.04 & 10.82 & $0.00^{*}$ & & & & \\
\hline $\mathrm{RMCH}$ & & & & 0.60 & 20.39 & $0.00 *$ & \\
\hline ATMR/4 & -0.08 & -2.95 & $0.00^{*}$ & -0.05 & -3.25 & $0.00^{*}$ & \\
\hline REER & -0.68 & -3.46 & $0.00 *$ & -0.28 & -2.38 & $0.02 * *$ & \\
\hline RHINV & 0.37 & 6.14 & $0.00 *$ & 0.23 & 6.12 & $0.00 *$ & 61 \\
\hline RESOMX & 0.12 & 2.55 & $0.01^{*}$ & 0.06 & 2.37 & $0.02 * *$ & \\
\hline C & -8.71 & -4.97 & $0.00^{*}$ & -4.19 & -5.30 & $0.00 *$ & \\
\hline$R^{2}$ & 0.92 & & & 0.98 & & & \\
\hline Adjusted $R^{2}$ & 0.92 & & & 0.98 & & & \\
\hline $\mathrm{SE}$ of regression & 0.10 & & & 0.05 & & & \\
\hline Long-run variance & 0.02 & & & 0.01 & & & \\
\hline Mean dependent var & 5.11 & & & 5.11 & & & \\
\hline SD dependent var & 0.36 & & & 0.36 & & & \\
\hline Sum squared resid & 1.22 & & & 0.28 & & & Table VI. \\
\hline \multicolumn{7}{|c|}{$\begin{array}{l}\text { Notes: Period Estimated: 1986Q1 2016Q4; The table reports two specifications of the long-run relation for } \\
\text { the baseline model. In specification II, I replace RDISP with RMCH; *indicates statistical significance at the } \\
1 \% \text { level; **the } 5 \% \text { level. Other proxies are also examined, including real per capita income, the ratio of the } \\
\text { population to housing completed, per capita real disposable income, the ratio of mortgage credit to GDP, } \\
\text { and the number of completed dwellings, without any significant improvements }\end{array}$} & $\begin{array}{r}\text { Fully modified least } \\
\text { squares estimate of } \\
\text { the long-run } \\
\text { determinants of } \\
\text { RHPs }\end{array}$ \\
\hline
\end{tabular}

response to a 1 per cent increase in the real ATMR. The results also show that real disposable income, one of the main determinants of housing affordability, is a key variable explaining RHP appreciation in the long run. More specifically, a 1 per cent increase in real disposable income should lead to a 1.04 per cent increase in RHPs unless there is a matching increase in supply. Although different studies use different explanatory variables and variable definitions, they may serve as a point of reference. For example, while Adams and Füss (2010) found the elasticities of the coefficients for real disposable household income and real interest rates to be valued at 0.99 and -0.45 , respectively, Claussen (2013) found these elasticities to be valued at 0.88 and -0.03 , respectively.

The REER is the third most important determinant affecting RHPs. A 10 per cent increase in the REER (e.g. deterioration of Swedish competitiveness) results in almost a 7 per cent decline in RHPS. Thus, gains in trade competitiveness lead to a significant degree of house price appreciation. RHINV also contributes to explaining housing price development in the long run, and an increase in real estate investment has a positive effect on housing price appreciation in the long run. This positive relationship is expected only in the short run and not in the long run because the desire of households to purchase homes increases demand for housing, which in turn drives housing prices up because the supply of housing is fixed in the short run. This positive relationship is upheld to the point at which property developers increase the production of housing and homeowners begin to sell their homes to capture the capital gains achieved through housing price increases. As a result, there is an increase in the supply of housing, which in turn limits house price appreciation. This leaves the following question: Why is this relationship maintained in the long run? The analysis in Section 4 is supported by other empirical studies (e.g. Boverket rapport, 2012; Sørensen 2013; Emanuelsson, 2015) citing high land prices, zoning laws, urban planning practices, rental market regulations and other legislation as major causes for the lack of Swedish housing supply responsiveness to the recent increase in Tobin's Q even in the long run. Financial wealth, proxied by RESOMX, also has a positive effect on housing price appreciation in the long run. A 1 per cent increase in financial 
IJHMA 11,1

results produces a 0.12 per cent increase in RHPs. Finally, unemployment is insignificant in determining house prices in the long run. Thus, unemployment plays a minor role in the evolution of housing demand and is not a key determinant of real housing price appreciation. The coefficient for the RMCH in Specification II is 0.60 , suggesting that the supply of credit is of direct and quantitatively important significance for house prices, separate from the fundamental factors governing the demand for houses. In other words, in the long run, a 10 per cent increase in the amount that can be borrowed will lead to a 6 per cent increase in actual house prices.

\subsection{Variance decomposition and impulse responses}

The main products of the VAR are variance decomposition and impulse response functions, which provide further understanding of the relationships between RHPs and their determinants. Variance decompositions are designed to determine what proportion of the changes in the RHP series can be attributed to changes in the lagged explanatory variables. Impulse responses are designed to determine what effects a one-unit shock of each explanatory variable will have on the RHP series over time. The ordering of variables is central to decomposition because it is effectively equivalent to an identifying restriction on the primitive form of the VAR; thus, I follow Brooks and Tsolacos (1999) and apply two orderings that are the exact opposite of one another and consider the sensitivity of the results. Table VII presents variance decompositions for the RHPs of the VAR for 1 to 36 steps ahead for the two variable orderings. Owing to the six-year forecasting horizon, the variable ordering has become almost irrelevant in most cases. As an interesting feature of the results, and consistent with the findings presented in the previous section, shocks to the REER, mortgage credit and after-tax real interest rate together account for average of 48 per cent of the variation in real housing prices in both orderings. The variance decomposition results also suggest that disturbances originating from current RHPs cause the most variability (average of 45 per cent of the variance) in future prices. The remaining 7 per cent of the variance is explained by the other five determinants. On the supply side, RHINV explains approximately only 1.5 per cent of house price variance in both orderings.

To further consider the effects of the fundamentals on RHPs, I calculated the impact multipliers (orthogonalized impulse responses) for the estimated VAR model. Two standard error bands were also calculated using the Monte Carlo integration approach. The estimated impulse responses are the dynamic responses of the endogenous variables (e.g. RHPs) to the standardized explanatory variables described above, and they outline the spread mechanism for these innovations through the estimated system. I use Cholesky decomposition techniques that involve moving average representations in the impulse response function. Hence, a change in one component has no effect on the other components because the components are orthogonal (uncorrelated). Moreover, the variance of the components takes a value of one. Thus, a one-unit innovation is merely an innovation of one standard deviation. Figure 9 shows the impulse responses associated with a unit shock in each of the 7 variables of the VAR system over a period of 36 quarters. All shocks are calibrated to be one standard deviation of the log level (with the exception of the real ATMR and unemployment rate) of the respective series. Considering the size and signs of the responses [as stated in Case and Shiller (1989)], there is evidence of sluggishness in RHPs: increases in prices over any year tend to be followed by increases in the subsequent period. Figure 9 shows that real ATMRs and REERs always have negative impacts on RHPs and that the effects of shocks do not decline even after 35 quarters. More specifically, a one standard deviation shock in the real ATMR leads to a 2 per cent decline in RHPs in quarter 6 and to an accumulated decline of 50 per cent after 36 quarters. Similarly, a one standard 


\begin{tabular}{|c|c|c|c|c|c|c|c|c|c|c|c|c|c|c|c|c|c|}
\hline \multirow[b]{2}{*}{ Quarter ahead } & \multicolumn{2}{|c|}{ RHP } & \multicolumn{2}{|c|}{ RDISP } & \multicolumn{2}{|c|}{$\mathrm{RMCH}$} & \multicolumn{2}{|c|}{ ATMR } & \multicolumn{2}{|c|}{ REER } & \multicolumn{2}{|c|}{ RHINV } & \multicolumn{2}{|c|}{ UNEMP } & \multicolumn{2}{|c|}{ RESOMX } & \multirow{2}{*}{$\begin{array}{l}\text { Swedish real } \\
\text { house prices }\end{array}$} \\
\hline & I & II & I & II & I & II & I & II & I & II & I & II & I & II & I & II & \\
\hline 1 & 100.0 & 81.8 & 0.0 & 0.2 & 0.0 & 7.1 & 0.0 & 0.0 & 0.0 & 0.0 & 0.0 & 7.4 & 0.0 & 0.4 & 0.0 & 3.1 & \\
\hline 2 & 95.3 & 72.2 & 0.2 & 0.2 & 2.4 & 13.5 & 0.1 & 0.7 & 1.3 & 2.1 & 0.0 & 7.9 & 0.5 & 1.4 & 0.2 & 2.0 & \\
\hline 3 & 83.3 & 58.8 & 2.4 & 4.8 & 7.5 & 21.7 & 0.1 & 0.5 & 3.1 & 3.1 & 0.3 & 7.8 & 1.4 & 2.2 & 1.9 & 1.2 & \\
\hline 4 & 76.1 & 51.3 & 2.3 & 5.1 & 11.9 & 28.7 & 0.5 & 0.3 & 4.1 & 4.3 & 0.2 & 6.5 & 1.8 & 2.7 & 3.2 & 1.1 & \\
\hline 5 & 71.9 & 47.5 & 1.5 & 4.0 & 14.3 & 33.8 & 1.8 & 0.3 & 4.5 & 5.4 & 0.1 & 5.1 & 1.8 & 2.9 & 4.0 & 1.0 & 63 \\
\hline 6 & 69.5 & 45.3 & 1.1 & 3.1 & 15.5 & 36.3 & 2.8 & 0.3 & 5.1 & 6.6 & 0.1 & 4.5 & 1.7 & 2.9 & 4.2 & 1.0 & \\
\hline 7 & 67.4 & 43.2 & 1.0 & 3.2 & 16.4 & 38.0 & 3.6 & 0.5 & 5.6 & 7.2 & 0.1 & 4.2 & 1.6 & 2.7 & 4.3 & 0.9 & \\
\hline 8 & 65.6 & 41.5 & 1.0 & 3.2 & 17.3 & 39.6 & 4.3 & 0.6 & 5.9 & 7.7 & 0.1 & 3.9 & 1.5 & 2.6 & 4.3 & 0.9 & \\
\hline 9 & 64.4 & 40.3 & 0.9 & 3.1 & 18.0 & 40.9 & 5.0 & 0.8 & 6.0 & 8.0 & 0.1 & 3.6 & 1.4 & 2.5 & 4.3 & 0.9 & \\
\hline 10 & 63.6 & 39.6 & 0.7 & 2.8 & 18.4 & 41.8 & 5.5 & 0.9 & 6.1 & 8.2 & 0.0 & 3.4 & 1.3 & 2.4 & 4.3 & 0.8 & \\
\hline 11 & 62.9 & 38.9 & 0.7 & 2.8 & 18.7 & 42.4 & 5.9 & 1.0 & 6.2 & 8.4 & 0.0 & 3.3 & 1.2 & 2.4 & 4.2 & 0.8 & \\
\hline 12 & 62.3 & 38.2 & 0.7 & 2.8 & 19.1 & 43.0 & 6.2 & 1.1 & 6.3 & 8.6 & 0.0 & 3.2 & 1.2 & 2.3 & 4.2 & 0.8 & \\
\hline 13 & 61.8 & 37.7 & 0.7 & 2.8 & 19.3 & 43.5 & 6.5 & 1.2 & 6.3 & 8.7 & 0.0 & 3.2 & 1.1 & 2.2 & 4.2 & 0.8 & \\
\hline 14 & 61.4 & 37.3 & 0.6 & 2.7 & 19.5 & 43.9 & 6.8 & 1.3 & 6.4 & 8.8 & 0.0 & 3.1 & 1.1 & 2.2 & 4.1 & 0.7 & \\
\hline 15 & 61.1 & 37.0 & 0.6 & 2.6 & 19.7 & 44.2 & 7.0 & 1.3 & 6.4 & 8.8 & 0.0 & 3.1 & 1.0 & 2.1 & 4.1 & 0.7 & \\
\hline 16 & 60.8 & 36.7 & 0.6 & 2.6 & 19.9 & 44.5 & 7.2 & 1.4 & 6.4 & 8.9 & 0.0 & 3.1 & 1.0 & 2.1 & 4.1 & 0.7 & \\
\hline 17 & 60.6 & 36.4 & 0.6 & 2.6 & 20.0 & 44.8 & 7.3 & 1.4 & 6.4 & 8.9 & 0.0 & 3.0 & 1.0 & 2.1 & 4.1 & 0.7 & \\
\hline 18 & 60.4 & 36.2 & 0.6 & 2.6 & 20.1 & 45.0 & 7.5 & 1.5 & 6.5 & 9.0 & 0.0 & 3.0 & 1.0 & 2.1 & 4.1 & 0.7 & \\
\hline 19 & 60.2 & 36.0 & 0.6 & 2.6 & 20.2 & 45.2 & 7.6 & 1.5 & 6.5 & 9.0 & 0.0 & 3.0 & 0.9 & 2.0 & 4.0 & 0.7 & \\
\hline 20 & 60.0 & 35.8 & 0.5 & 2.6 & 20.3 & 45.3 & 7.7 & 1.6 & 6.5 & 9.1 & 0.0 & 3.0 & 0.9 & 2.0 & 4.0 & 0.7 & \\
\hline 21 & 59.9 & 35.7 & 0.5 & 2.5 & 20.4 & 45.5 & 7.8 & 1.6 & 6.5 & 9.1 & 0.0 & 3.0 & 0.9 & 2.0 & 4.0 & 0.7 & \\
\hline 22 & 59.7 & 35.6 & 0.5 & 2.5 & 20.4 & 45.6 & 7.9 & 1.6 & 6.5 & 9.1 & 0.0 & 2.9 & 0.9 & 2.0 & 4.0 & 0.7 & \\
\hline 23 & 59.6 & 35.4 & 0.5 & 2.5 & 20.5 & 45.7 & 7.9 & 1.7 & 6.5 & 9.1 & 0.0 & 2.9 & 0.9 & 2.0 & 4.0 & 0.7 & \\
\hline 24 & 59.5 & 35.3 & 0.5 & 2.5 & 20.6 & 45.8 & 8.0 & 1.7 & 6.5 & 9.2 & 0.0 & 2.9 & 0.9 & 1.9 & 4.0 & 0.7 & \\
\hline 25 & 59.4 & 35.2 & 0.5 & 2.5 & 20.6 & 45.9 & 8.1 & 1.7 & 6.5 & 9.2 & 0.0 & 2.9 & 0.9 & 1.9 & 4.0 & 0.7 & \\
\hline 26 & 59.3 & 35.1 & 0.5 & 2.5 & 20.7 & 46.0 & 8.1 & 1.7 & 6.5 & 9.2 & 0.0 & 2.9 & 0.8 & 1.9 & 4.0 & 0.7 & \\
\hline 27 & 59.3 & 35.1 & 0.5 & 2.5 & 20.7 & 46.0 & 8.2 & 1.7 & 6.5 & 9.2 & 0.0 & 2.9 & 0.8 & 1.9 & 4.0 & 0.7 & \\
\hline 28 & 59.2 & 35.0 & 0.5 & 2.5 & 20.7 & 46.1 & 8.2 & 1.7 & 6.5 & 9.2 & 0.0 & 2.9 & 0.8 & 1.9 & 4.0 & 0.7 & \\
\hline 29 & 59.1 & 34.9 & 0.5 & 2.5 & 20.8 & 46.2 & 8.3 & 1.8 & 6.5 & 9.2 & 0.0 & 2.9 & 0.8 & 1.9 & 4.0 & 0.6 & \\
\hline 30 & 59.1 & 34.9 & 0.5 & 2.5 & 20.8 & 46.2 & 8.3 & 1.8 & 6.5 & 9.3 & 0.1 & 2.9 & 0.8 & 1.9 & 3.9 & 0.6 & \\
\hline 31 & 59.0 & 34.8 & 0.5 & 2.5 & 20.8 & 46.3 & 8.3 & 1.8 & 6.5 & 9.3 & 0.1 & 2.9 & 0.8 & 1.9 & 3.9 & 0.6 & \\
\hline 32 & 59.0 & 34.7 & 0.5 & 2.5 & 20.9 & 46.3 & 8.4 & 1.8 & 6.5 & 9.3 & 0.1 & 2.9 & 0.8 & 1.9 & 3.9 & 0.6 & \\
\hline 33 & 58.9 & 34.7 & 0.5 & 2.5 & 20.9 & 46.4 & 8.4 & 1.8 & 6.5 & 9.3 & 0.1 & 2.9 & 0.8 & 1.9 & 3.9 & 0.6 & \\
\hline 34 & 58.9 & 34.7 & 0.5 & 2.4 & 20.9 & 46.4 & 8.4 & 1.8 & 6.5 & 9.3 & 0.1 & 2.9 & 0.8 & 1.9 & 3.9 & 0.6 & \\
\hline 35 & 58.8 & 34.6 & 0.5 & 2.4 & 20.9 & 46.4 & 8.4 & 1.8 & 6.5 & 9.3 & 0.1 & 2.9 & 0.8 & 1.9 & 3.9 & 0.6 & \\
\hline 36 & 58.8 & 34.6 & 0.5 & 2.4 & 20.9 & 46.5 & 8.5 & 1.8 & 6.5 & 9.3 & 0.1 & 2.9 & 0.8 & 1.9 & 3.9 & 0.6 & \\
\hline $\begin{array}{l}\text { Notes: The ta } \\
\text { variable orderi } \\
\text { rate together a } \\
\text { originating froi }\end{array}$ & ngs. T & $\begin{array}{l}\text { ts } v \\
\text { res } \\
\text { for }\end{array}$ & & age & & $\% 0$ & $n$ & $\begin{array}{l}\text { ar1 } \\
\text { ity }\end{array}$ & & the & tre & $\mathrm{si}$ & & & & $\begin{array}{l}\text { two } \\
\text { erest } \\
\text { nces }\end{array}$ & $\begin{array}{r}\text { Table VII. } \\
\text { Variance } \\
\text { decompositions for } \\
\text { the RHPs' residuals }\end{array}$ \\
\hline
\end{tabular}

deviation shock in the REER leads to a 1.6 per cent decline in RHPs in quarter 4 and to an accumulated decline of 46 per cent after 35 quarters.

Unsurprisingly, an unexpected rise in mortgage credit has a positive and significant effect on RHPs, and the effects of the shock do not decline even after 35 quarters. More specifically, a one standard deviation shock in bank credit leads to a 1.2 per cent increase in RHPs and to an accumulated increase of 82 per cent after 35 quarters. Similarly, the effect of RESOMX is also positive and significant, though somewhat less persistent and with a wider confidence band, and it appears to exercise its effect with some lags with respect to RHPs. A one standard deviation shock in RESOMX leads to a 1.2 per cent rise in RHPs in quarter 5 


\section{IJHMA}

11,1

\section{4}

Figure 9.

Impulse response of RHPs to one standard deviation of their fundamentals

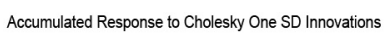

Accumulated Response of LRHP to LRCSP
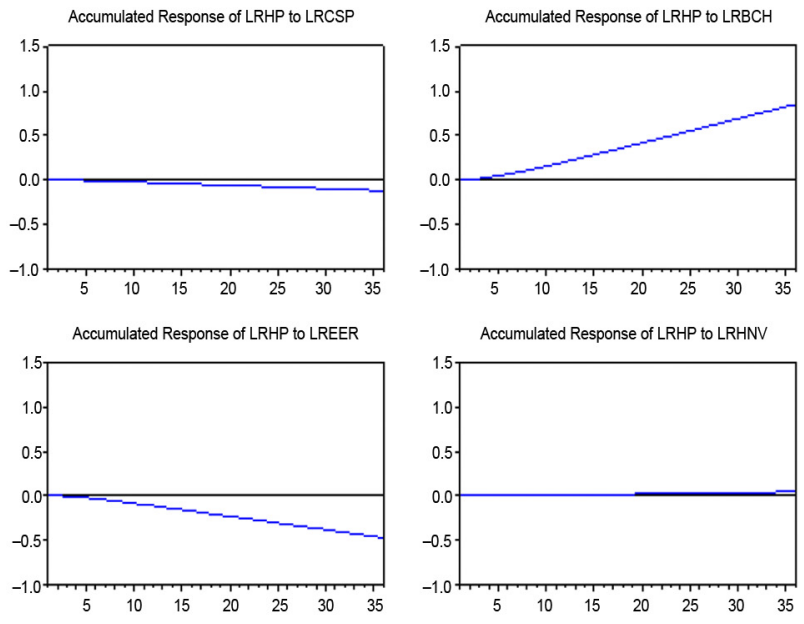
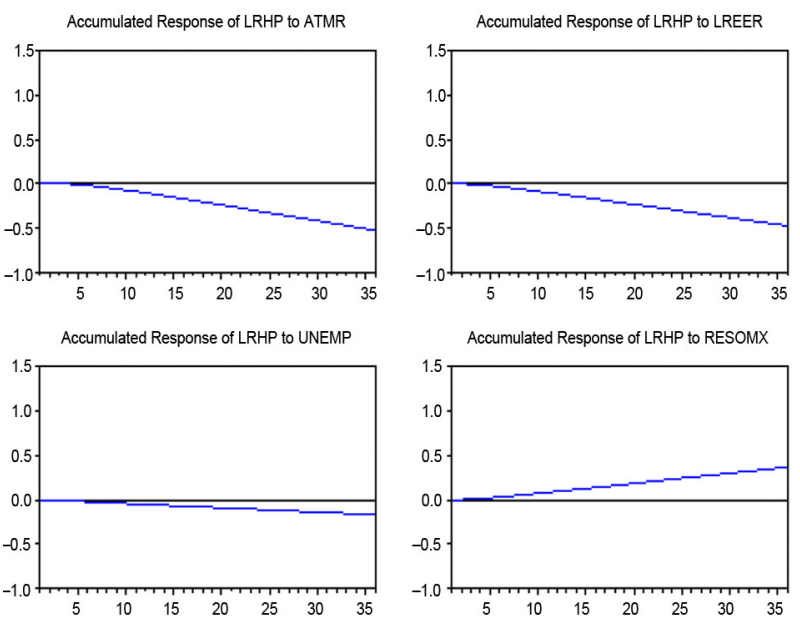

Notes: The figure shows the accumulated response of the RHPs to a 1 per cent shock in their determinants: RHP index; real disposable income (RDISP); RMCH; real ATMR; REER; RHINV; unemployment (UNEMP); and residual of stock prices (RESOMX). The response is based on Cholesky and vector error correction specifications. All data are transformed to their natural logarithms, with the exception of ATMR and unemployment

and to an accumulated increase of 35 per cent after 35 quarters. In this way, the evidence does support the financial accelerator mechanism applied to housing assets at the economywide level, which asserts that a minor change in financial markets can produce a significant change in real housing prices and create a feedback loop. The effects of real disposable income, unemployment and RHINV were found to be insignificant.

In summary, the results of impulse response and variance decomposition indicate that the growth of the mortgage credit and financial wealth as well as decreases in the ATMR and the improvement of Swedish competitiveness are the main causes of Swedish house appreciation. As a robustness check, I next quantify the impact of these factors on the growth of house prices in the short run.

\subsection{Analysis of short-run dynamics: a robustness check}

I adopt a general-to-specific approach in assessing the determinants of house price dynamics. I begin by including all explanatory factors identified in the long-run relationship [equation (4)] with statistically insignificant variables eliminated. I have also included three 
dummies - a dummy for the bank and property crises of the early 1990s (DUM92), a dummy for the introduction of a mortgage cap in October 2010 (DUM2010) and a dummy for the implementation of an amortization requirement in June 2016 (DUM2016) - as well as three seasonal terms. Finally, I include the real disposable income and the mortgage credit in the same regression, as orthogonalization is not an issue here because the variables considered are expressed as percentage changes.

Before proceeding to interpret the results, a number of residual diagnostic and parameter stability tests were performed to ensure that the residual of the short-run estimated equation was white noise. Appendix 2 shows the results of the Breusch-Godfrey Serial Correlation LM test, the cumulative sum residual (CUSUM) statistics and the variance inflation factor (VIF) test. Overall, these results show that the model specifications were well adapted to the unknown data generation process and that the residual of the estimated equation appears to be white noise.

Table VIII presents the estimation results of the short-run dynamics, equation (4), with the elimination of statistically insignificant variables, except dummies. A few features of the short-run relationship between real housing prices and their determinants shown in Table VIII are worth highlighting. First, changes in real housing prices in the previous periods are significant explanatory elements of the evolution of housing prices in the short run. This finding supports the ideas advanced by Shiller (2007) highlighting the powerful role of

\begin{tabular}{lccc}
\hline Variable & Coefficient & t-statistic & Prob. \\
\hline C & -0.02 & -7.82 & $0.00^{*}$ \\
D(RHP(-1)) & 0.42 & 5.60 & $0.00^{*}$ \\
D(ATMR(-4))/4 & -0.02 & -2.99 & $0.00^{*}$ \\
D(RHINV(-8)) & -0.08 & -2.74 & $0.01^{*}$ \\
D(RMCH) & 0.22 & 3.44 & $0.00^{*}$ \\
D(RMCH(-1)) & 0.14 & 2.01 & $0.05^{* *}$ \\
D(RMCH(-4)) & 0.20 & 3.02 & $0.00^{*}$ \\
D(REER(-3)) & -0.11 & -2.41 & $0.02^{* *}$ \\
RESOMX(-8) & 0.01 & 2.77 & $0.01^{*}$ \\
@QUARTER $=1$ & 0.03 & 6.42 & $0.00^{*}$ \\
@QUARTER $=2$ & 0.03 & 7.47 & $0.00^{*}$ \\
@QUARTER $=3$ & 0.02 & -3.01 & $0.00^{*}$ \\
DUM1992 & -0.01 & -1.6 & $0.01^{*}$ \\
DUM2010 & -0.001 & 1.75 & 0.12 \\
DUM 2016 & 0.002 & & 0.23 \\
$R^{2}$ & 0.70 & Mean dependent var & 0.01 \\
Adjusted $R^{2}$ & 0.67 & SD dependent var & 0.02 \\
SE of regression & Akaike info criterion & -5.78 \\
Sum squared resid & Schwarz criterion & -5.49 \\
Log likelihood & 0.01 & Hannan-Quinn criter & -5.66 \\
-statistic & Durbin-Watson stat & 2.17 \\
Prob (F-statistic) & 344.18 & &
\end{tabular}

Notes: Sample period: 1986Q1-2016Q4; The table reports the results of short-run RHP dynamics. D refers to the first difference, and the negative number in the parentheses refers to the number of lags. See Table I for the definition of the variables. I also examined two dummies - a dummy for the bank and property crises of the early 1990s and a dummy for the introduction of a mortgage cap in October 2010 - as well as three seasonal terms. The dummies turned out to be insignificant and therefore were removed from the regression. *indicates statistical significance at the $1 \%$ level; $* *$ the $5 \%$ level. All data are transformed to their natural logarithms, with the exception of ATM, RESOMX and UNEMP
Swedish real house prices

65

$-2$ 
IJHMA 11,1

expectations in the formation of prices in this market and emphasizing the fact that during booms, households decide to buy such assets for speculative reasons. My finding is also consistent with the findings of Brooks and Tsolacos (1999), who found that the most significant influence on real estate series is the lagged values of those series themselves. Second, growth rates in the mortgage credit given by banks and other financial institutions have positive effects on changes in RHPs. The elasticity of RHP changes in relation to mortgage credit growth (0.22) is significant at the 1 per cent level. These results suggest that the relaxation of credit standards encourages the entry of new homebuyers into the market and helps increase demand for housing, which is in turn absorbed by prices. Third, my proxy of financial wealth, RESOMX, has positive effects on changes in RHPs. In the short run, a 1 per cent increase in RESOMX will lead to an increase in housing prices of 1 per cent, which is significant at the 1 per cent level. Fourth, changes in real residential investments, the REER and real ATMRs all lead to RHP deflation. The elasticities of the growth rates of real residential investments $(-0.08)$, REERs $(-0.11)$ and real ATMRs $(-0.02)$ are all significant and negative. Fourth, the effects of changes in real disposable income and unemployment on real price changes are insignificant. Finally, the impact of the two lending restrictions that were implemented after the financial crisis - the mortgage cap in October 2010 (DUM2010) and the amortization requirement in June 2016 (DUM2016) - are insignificant. Thus, although the use of these macroprudential measures is still in its early stages and there is limited international experience to draw from, the available data suggest that these measures are ineffective in stabilizing the housing market.

A comparison of the long- and short-run estimates (Tables V and VIII) reveal key findings. First, the effects of real ATMRs remain significant at the 1 per cent level and negative regardless of the time horizon considered. Regarding fiscal authority interventions in the real estate market, my econometric results present empirical evidence on how they can mitigate hikes in housing prices by removing interest rate tax deductibles or by taxing property. Second, the effects of REERs also remain negative and significant regardless of the time horizon considered. In the short run, a 1 per cent deterioration of Swedish competitiveness (i.e. an increase in the REER) will lead housing prices to fall by 0.11 per cent, which is significant at the 1 per cent level. This finding also holds for the long run, where the cointegrating equation also highlights the significance of the REER at the equilibrium position.

Third, the effects of mortgage credit growth are positive and significant in determining RHP appreciation in the short run. This variable is also significant and positive in determining housing prices in the equilibrium relationship (Specification II). My estimates support the findings of Igan and Loungani (2012) and Arestis and Gonzalez (2013), who found significant effects of the mortgage credit and interest rates on house prices.

Fourth, growth of real residential investment is found to be significant in determining housing prices in both the short- and long-run analyses but with different signs. While this variable has an unexpected positive sign in the long run, it has an expected negative sign in the short run, suggesting that an increase in real investment leads to house price deflation. Fifth, the impact of my proxy of financial wealth, RESOMX, also remains significant and positive regardless of the time horizon considered. Finally, I note that changes in real disposable income and unemployment are insignificant in determining housing prices in the short- and long-run analyses.

\section{Conclusion}

Never before have real housing prices in Sweden increased so quickly and for so long. Prices rose by 43 per cent from 2009 to 2016, with by far the largest surge occurring in the larger 
urban areas. My main finding is that shocks to the REER, mortgage credit and the real aftertax interest rate together account for most of the variation in real housing prices in the long and short run.

My analysis suggests that the housing price boom in Sweden has largely been driven by three fundamental factors:

(1) highly expansionary monetary policies in the form of exceptionally low policy interest rates and high mortgage credit growth;

(2) structural factors, such as housing supply constraints, changes in tax policies that have encouraged house ownership, and tax incentives that have kept amortization rates low; and

(3) improvement in Sweden's competitiveness due to a weak krona and a lower inflation rate relative to those of foreign countries.

Regarding the two macroprudential measures that have been implemented since the financial crisis - LTV and the voluntary amortization requirement - my econometric results suggest that they are ineffective in dampening mortgage credit or house price growth in the current low-interest-rate environment. Thus, the key to easing pressure on prices and reducing the risk for financial instability is to focus on these fundamentals that are driving the housing market boom. This will require macroprudential measures directly targeting the demand side, including the introduction of statutory amortization rates, lower LTV caps and the implementation of DTI limits to improve households' resilience to shocks. More essentially, gradually phasing out the tax deductibility of mortgage interest would reduce incentives for mortgage demand and household debt accumulation. In the longer term, housing supply rigidities must be addressed to cope with the growing demand and urbanization trends. A number of policies could increase the stock of affordable housing, including continuing reforms to zoning, permitting and the rentsitting process, as well as public investment. In addition, it is vital to improve the allocation of the existing housing stocks through, for example, a tax reform that increases the very low property tax rate while reducing capital gains taxation on housing investment.

\section{Notes}

1. The real effective exchange rate series takes into account not only changes in market exchange rates but also variations in relative price levels (using, respectively, consumer prices and unit labor costs in manufacturing), and it is therefore used as an indicator of competitiveness.

2. Amortization requirements applied to new loans and came into force on June 1, 2016; they implied that new loans for apartments and houses must be amortized by 2 per cent per year for an LTV of 70 per cent and by 1 per cent for an LTV of 50 per cent. In addition, a debt-to-income (DTI) limit of 600 per cent has recently been proposed by the Swedish FSA (Finansinspektionen) as a possible new measure of macroprudential policy.

3. For a detailed discussion on the effects of tax reforms on the supply of housing in Sweden, see Emanuelsson (2015).

4. These correlations are not shown here due to space limitations but are available upon request. Other transformations were also examined, including real per capita income, the population relative to completed stock, per capita real disposable income and the ratio of mortgage credit to GDP without any significant improvements. 
IJHMA 11,1
5. We rely on the maximum eigenvalue tests since the trace tests tend to have more distortion in small samples (Lüutkepohl et al., 2001). We have also imposed restrictions on the cointegrating vector to test which variable is part of the cointegration relationships and whether they do adjust to the long-term equilibrium.

\section{References}

Adams, Z. and Füss, R. (2010), "Macroeconomic determinants of international housing markets", Journal of Housing Economics, Vol. 19 No. 1, pp. 38-50.

Akbari, A.H. and Aydede, Y. (2012), "Effects of immigration on house prices in Canada", Applied Economics, Vol. 44 No. 13, pp. 1645-1658.

Ambrose, B., Eichholtz, P. and Lindenthal, T. (2013), "House prices and fundamentals: 355 years of evidence", Journal of Money, Credit and Banking, Vol. 45 No. 2-3, pp. 477-491.

Annett, A. (2005), "Euro area policies: selected issues", IMF Country Report, No. 05/266; 2005, IMF, Washington, DC.

Arestis, P. and Gonzalez, A. (2013), "Modeling the housing market in OECD countries", Working Paper No. 764, Levy Economics Institute of Bard College.

Barot, B. (2001), “An econometric demand-supply model for Swedish private housing”, International Journal of Housing Policy, Vol. 1 No. 3, pp. 417-444.

Barot, B. and Yang, Z. (2002), "House prices and housing investment in Sweden and the UK: econometric analysis for the period 1970-1998", Review of Urban and Regional Development Studies, Vol. 14, pp. 189-216.

Bergman, U., Sørensen, P. and Sillemann, B. (2015), "House prices in Denmark and Sweden", in Andersen, T.M., Bergman, M. and Jensen, S.E.H. (Eds), Reform Capacity and Macroeconomic Performance in the Nordic Countries, Oxford University Press, Oxford.

Brooks, C. (2014), Introductory Econometrics for Finance, Cambridge University Press, Cambridge, MA.

Brooks, C. and Tsolacos, S. (1999), "The impact of economic and financial factors on UK property performance", Journal of Property Research, Vol. 16 No. 2, pp. 139-152.

Case, K.E., Quigley, J. and Shiller, R.J. (2013), "Wealth effects revisited: 1975-2012”, NBER Working Papers 18667, National Bureau of Economic Research.

Case, K.E. and Shiller, R.J. (1989), "The efficiency of the market for single-family homes", American Economic Review, Vol. 79, pp. 125-137.

Claussen, C. (2013), “Are Swedish houses overpriced?”, International Journal of Housing Markets and Analysis, Vol. 6, pp. 180-196.

Claussen, C., Jonsson, M. and Lagerwall, B. (2011), A Macroeconomic Analysis of House Prices in Sweden, The Riksbank's Commission of Inquiry Into Risk on the Swedish Housing market, Sveriges Riksbank.

DiPasquale, D. and Wheaton, W. (1996), Urban Economics and Real Estate Markets, Prentice Hall, Rio de Janeiro.

Emanuelsson, R. (2015), "Supply of housing in Sweden”, Sveriges Riksbank Economic Review, Sveriges Riksbank, Stockholm.

Engle, R.F. and Granger, C.W.J. (1987), “Co-integration and error correction: Representation, estimation, and testing", Econometrica, Vol. 55 No. 2, pp. 251-276.

European Commission (2014), "Country report on macroeconomic imbalances in Sweden”, Occasional Papers 186, European Commission.

Fratzscher, M., Juvenal, L. and Sarno, L. (2007), “Asset prices, exchange rates and the current account”, Working Paper Series 790, European Central Bank. 
Frisell, L. and Yazdi, M. (2010), "Prisutvecklingen på den svenska bostadsmarknaden-en fundamental analys", Sveriges Riksbank, Penning-Och Valutapolitik, Vol. 2010, pp. 3-37.

Gallin, J. (2006), "The long-run relationship between house prices and income: evidence from local housing markets", Real Estate Economics, Vol. 34 No. 3, pp. 417-438.

Gattini, L. and and Hiebert, P. (2010), "Forecasting and assessing euro area house prices through the lens of key fundamentals", Working Paper Series No 1249, European Central Bank.

Girouard, N., Kennedy, M., van den Noord, P. and André, C. (2006), "Recent House Price Developments: The Role of Fundamentals", OECD Working Paper No. 475, OECD.

Gonzalez, L. and Ortega, F. (2013), "Immigration and housing booms: evidence from Spain", Journal of Regional Science, Vol. 53 No. 1, p. 3759.

Gyimah, S.O., Walters, D. and Phythian, K.L. (2005), "Ethnicity, immigration and housing wealth in toronto", Canadian Journal of Urban Research, Vol. 14 No. 2, pp. 338-364.

Hort, K. (1998), "The determinants of urban house price fluctuations in Sweden 1968-1994”, Journal of Housing Economics, Vol. 7, pp. 93-120.

Igan, D. and Loungani, P. (2012), “Global housing cycles”, IMP Working Paper No12/217, IMP.

Justiniano, A., Primiceri, G.E. and Tambalotti, A. (2014), "The effects of the saving and banking glut on the US economy", Journal of International Economics, Vol. 92, pp. S52-S67.

McCue, T. and Kling, J. (1994), "Real estate returns and the macroeconomy: some empirical evidence from real estate investment trust data, 1972-1991”, Journal of Real Estate Research, Vol. 9, pp. 277-287.

Mendicino, C. and Punzi, M. (2014), "House prices, Capital inflows and macroprudential policy", Journal of Banking \& Finance, Vol. 49, pp. 337-355.

Lüutkepohl, H., Saikkonen, P. and Trenkler, C. (2001), "Maximum eigenvalue versus trace tests for the cointegrating rank of a VAR process", The Econometric Journal, Vol. 4 No. 2.

Meen, G. (2002), “The time-series behavior of house prices: a transatlantic divide?”, Journal of Housing Economics, Vol. 11 No. 1, pp. 1-23.

Schnure, C. (2005), "United States: selected issues”, IMF Country Report, No. 05/258, IMF.

Shiller, R.J. (2007), "Low real interest rates and high asset prices”, Unpublished Paper, for Presentation at Brookings Panel on Economic Activity, Washington DC.

Sørensen, P.B. (2013), “The Swedish housing market: trends and risks”, Rapport Till Finanspolitiska Rådet.

Sá, F., Towbin, P. and Wieladek, T. (2014), "Capital inflows, financial structure and housing booms", Journal of the European Economic Association, Vol. 12 No. 2, pp. 522-546.

Swedish National Board of Housing, Building and Planning (2012), Boverket, Bostadsbrist ur ett marknadsperspektiv (Housing shortage from a market perspective).

Xu, L. and Tang, B. (2014), "On the determinants of UK house prices", International Journal of Economics and Research, Vol. 5, pp. 57-64.

\section{Further reading}

Andrews, D. (2010), "Real house prices in OECD countries: the role of demand shocks and structural and policy factors", Working Papers No. 831, OECD Economics Department, OECD Publishing.

Englund, P. (2015), “The Swedish 1990s banking crisis: a revisit in the light of recent experience”, paper presented at the Riksbank Macroprudential Conference, Stockholm, 23-24 June. 
IJHMA

11,1

\section{Appendix 1}

RHP

70

RDISP

ATMR

REER

RHINV

Real Bank Credit for housing purchases, RRMCH

Residential of stock price index, RESOMX

Real Construction Cost, RCC

Unemployment, UNEMP

Table AI.

Housing Completed, COMP

Variable description and data sources
Population to Housing

Completed
House Prices index deflated by consumer price index rebased to 1986q1 in logs. The Index estimates development of prices and values of the existing stock of one- or two-dwelling buildings for the whole country. The index is constructed based on repeated sales and appraisals estimates and takes into consideration that the houses sold may not be a random sample of the housing stock and that the mix or composition of houses may vary from one quarter/year to the next. One- or two-dwelling buildings for permanent dwelling include detached one- or two-dwelling buildings, terraced houses and linked buildings. Data source: Datastream and Statistics Sweden Net RDISP, seasonally adjusted, in logs. Data source: OECD Economic Outlook, BIS and Statistics Sweden

Real after tax deductibility mortgage rate. It is calculates using: $r_{t}^{\mathrm{m}}\left(1-\tau_{t}\right)-$ $\pi_{t}$. where $\mathrm{r}_{\mathrm{t}}$ is a five years mortgage rate, $\tau_{t}$ is the amount of interest rate tax-deduction (50\% from 1986 to 1989 and $30 \%$ thereafter) and $\pi_{t}$ is the inflation rate. Data source: Statistics Sweden

Defined as the nominal effective exchange rate (a measure of the value of the Swedish krona against a weighted average of Sweden's largest trade partners) divided by a price deflator rebased to 1986q1 in logs. Data source: OECD Economic Outlook

Real gross fixed capital formation - Housing deflated by CPI. Data source: Statistics Sweden, Datastream, and own calculation

Lending to households from monetary and financial institutions, housing (MFI) deflated by CPI. Data source: Statistics Sweden and Riksbanken It is our proxy of financial wealth. It is residual resulted from regressing the housing price index on the Stock market index (OMXS30). Data source: Statistics Sweden and Riksbanken

Nominal cost of construction deflated by CPI. Data source: Statistics Sweden and Riksbanken

Harmonized unemployment rate, all persons. Data source: OECD Indicators and Statistics Sweden

Dwellings completed in newly constructed buildings one- or two-dwelling buildings. Data source: Statistics Sweden

The ratio of population to housing completed. Statistics Sweden and own calculation 


\begin{tabular}{lllr}
\hline F-statistic & 0.92 & Prob. F(12.101) & 0.39 \\
Obs $\times R$-squared & 2.016 & Prob. chi-square(2) & 0.35
\end{tabular}

Notes: The table reports the F-statistic and the chi-squared statistics as well as their $p$-values on the Breusch-Godfrey Serial Correlation LM Test. The F-statistic and chi-squared statistic $p$-values of 0.26 and 0.23 , respectively, do not reject the null hypothesis of no serial correlation.

0.39

0.35

\section{.}

Breusch-Godfrey

serial correlation LM test

\begin{tabular}{lrlr}
\hline F-statistic & 1.20 & Prob. F(10.104) & 0.19 \\
Obs $\times R$-squared & 11.92 & Prob. chi-square(10) & 0.20 \\
Scaled explained SS & 18.06 & Prob. chi-square(10) & 0.04
\end{tabular}

Notes: The table reports the results of heteroskedasticity based on the Breusch-Pagan-Godfrey test. The Obs $\times R^{2}$ value is 0.32 , and thus, I cannot reject the null hypothesis of homoscedasticity
Table AIII.

Heteroskedasticity

test: Breusch-

Pagan-Godfrey

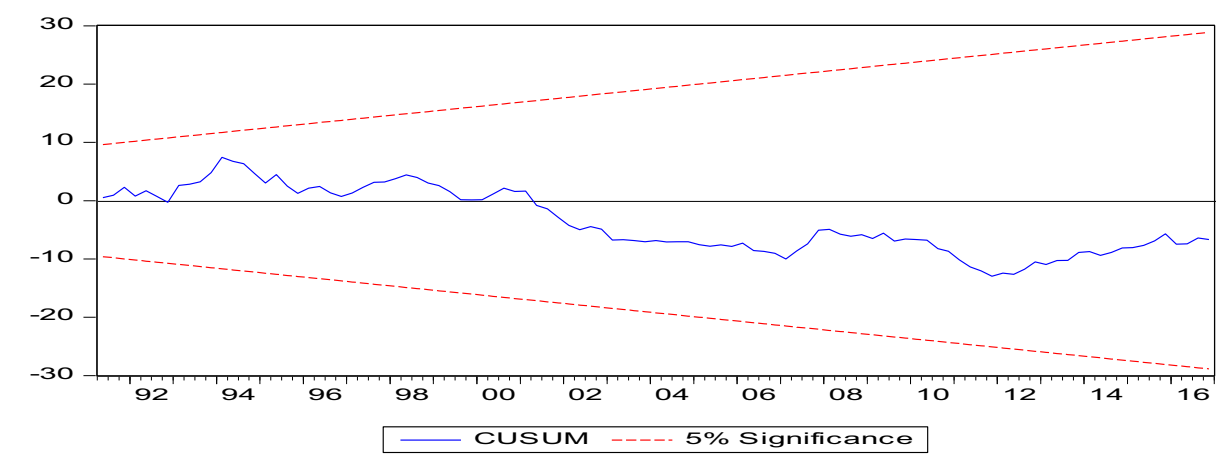

Notes: The figure plots the cumulative sum residual (CUSUM) statistics derived from the residuals of the recursive estimation and a set of \pm 2 standard error bands. The figure shows no signs of instability, as the CUSUM values remain inside the bands

Figure A1. CUSUM stability test 


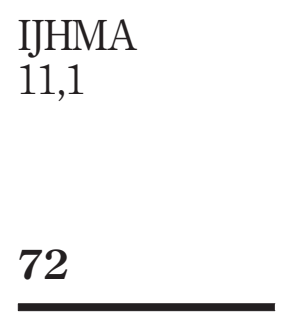

Figure A2.

Actual vs fitted and residual

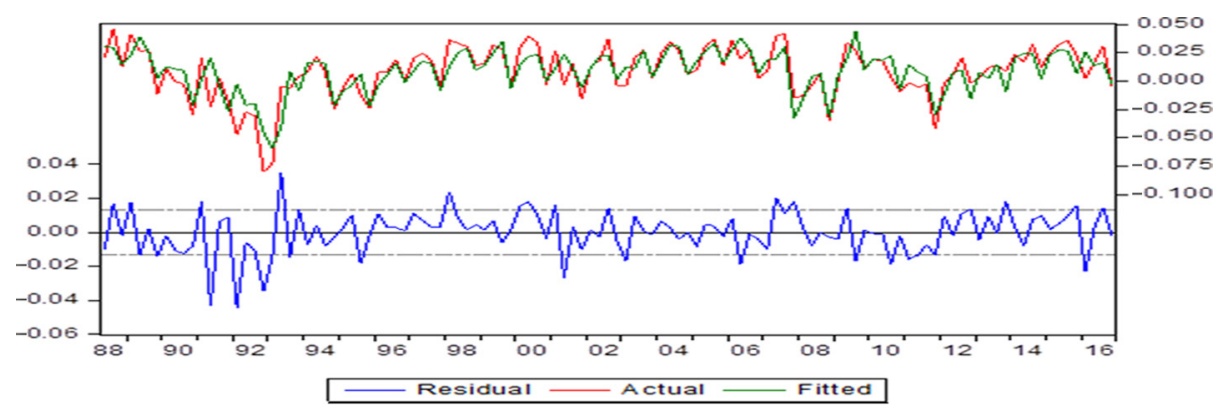

Notes: The figure plots the actual value against the fitted estimates as well as the behavior of the residuals. The figure shows that the residuals and the fitted values are uncorrelated, as they should be in a homoskedastic linear model with normally distributed errors

\begin{tabular}{lccc}
\hline Variable & $\begin{array}{c}\text { Coefficient } \\
\text { Variance }\end{array}$ & $\begin{array}{c}\text { Uncentered } \\
\text { VIF }\end{array}$ & $\begin{array}{c}\text { Centered } \\
\text { VIF }\end{array}$ \\
\hline C & 0.00 & 5.45 & NA \\
D(LRHP(-1)) & 0.01 & 2.26 & 1.94 \\
D(ATMR(-4)) & 0.00 & 1.23 & 1.23 \\
D(LRHINV(-8)) & 0.00 & 1.20 & 1.19 \\
D(LRMCH) & 0.00 & 1.68 & 1.19 \\
D(LRMCH(-1)) & 0.00 & 1.81 & 1.27 \\
D(LRMCH(-4)) & 0.00 & 1.82 & 1.28 \\
D(LREER(-3)) & 0.00 & 1.03 & 1.03 \\
RESOMX(-8) & 0.00 & 1.30 & 2.10 \\
@QUARTER = & 0.00 & 2.77 & 1.60 \\
@QUARTER = & 0.00 & 2.14 & 1.66 \\
@QUARTER $=3$ & 0.00 & 2.22 &
\end{tabular}

Table AIV. VIFs
Notes: Sample period: 1986Q1-2016Q4; The table shows centered and uncentered VIFs. A VIF value greater than 8 roughly indicates significant multicollinearity. D refers to the first difference of the variable. I have also included three dummies - a dummy for the bank and property crises of the early 1990s (DUM92), a dummy for the introduction of a mortgage cap in October 2010 (DUM2010) and a dummy for the implementation of an amortization requirement in June 2016 (DUM2016) - as well as three seasonal terms. The results show no sign of multicollinearity the short-run estimate

\section{Corresponding author}

Maher Asal can be contacted at: maher.asal@hv.se

For instructions on how to order reprints of this article, please visit our website: 